\title{
Recovery of Phosphorus from Waste Water Profiting from Biological Nitrogen Treatment: Upstream, Concomitant or Downstream Precipitation Alternatives
}

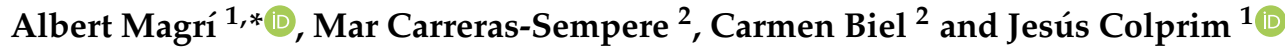 \\ 1 LEQUIA, Institute of the Environment, University of Girona, Campus Montilivi, Carrer Maria Aurèlia \\ Capmany 69, E-17003 Girona, Catalonia, Spain; jesus.colprim@udg.edu \\ 2 IRTA, Institute of Agrifood Research and Technology, Sustainable Plant Protection Program, Ctra. de Cabrils, \\ km 2, E-08348 Cabrils (Barcelona), Catalonia, Spain; mar.carreras@irta.cat (M.C.-S.); \\ carmen.biel@irta.cat (C.B.) \\ * Correspondence: albert.magri@udg.edu or albert.magri@gmail.com; Tel.: +34-972-419-542
}

Received: 19 June 2020; Accepted: 14 July 2020; Published: 18 July 2020

\begin{abstract}
Mined phosphate rock is the largest source of phosphorus $(\mathrm{P})$ for use in agriculture and agro-industry, but it also is a finite resource irregularly distributed around the world. Alternatively, waste water is a renewable source of $\mathrm{P}$, available at the local scale. In waste water treatment, biological nitrogen $(\mathrm{N})$ removal is applied according to a wide range of variants targeting the abatement of the ammonium content. Ammonium oxidation to nitrate can also be considered to mitigate ammonia emission, while enabling $\mathrm{N}$ recovery. This review focuses on the analysis of alternatives for coupling biological $\mathrm{N}$ treatment and phosphate precipitation when treating waste water in view of producing P-rich materials easily usable as fertilisers. Phosphate precipitation can be applied before (upstream configuration), together with (concomitant configuration), and after (downstream configuration) $\mathrm{N}$ treatment; i.e., chemically induced as a conditioning pre-treatment, biologically induced inside the reactor, and chemically induced as a refining post-treatment. Characteristics of the recovered products differ significantly depending on the case studied. Currently, precipitated phosphate salts are not typified in the European fertiliser regulation, and this fact limits marketability. Nonetheless, this topic is in progress. The potential requirements to be complied by these materials to be covered by the regulation are overviewed. The insights given will help in identifying enhanced integrated approaches for waste water treatment, pointing out significant needs for subsequent agronomic valorisation of the recovered phosphate salts, according to the paradigms of the circular economy, sustainability, and environmental protection.
\end{abstract}

Keywords: precipitated phosphate salts; calcium phosphate; magnesium phosphate; struvite; waste water treatment; nitrification; denitrification; anammox; resource recovery; circular economy

\section{Introduction}

Phosphorus $(\mathrm{P})$ is an essential element for all living organisms as a constituent of nucleic acids, energy-transfer molecules in metabolism, cell membranes, and body building blocks. Phosphorus is also an irreplaceable nutrient, non-manufacturable nor destroyable. Its shortage limits crop growth and agri-food production [1]. Yet, when $\mathrm{P}$ is discharged in excess to aquatic and terrestrial ecosystems, it acts as a pollutant, causing eutrophication and nutrient imbalances [2]. Phosphorus has no significant gaseous phase, so it cannot flow freely in the atmosphere. This is in contrast with the nature of the other essential elements supporting life—carbon $(\mathrm{C})$, nitrogen $(\mathrm{N})$, oxygen $(\mathrm{O})$ and hydrogen $(\mathrm{H})$. Nowadays, 
mined phosphate rock is the largest source of $\mathrm{P}$ for use in both agriculture and industry. However, this is a finite resource irregularly distributed around the world. This means that $\mathrm{P}$ availability is linked to geopolitical considerations that may lead to uncertainties about supplies [3,4]. In this regard, the creation of (inter)national strategic $P$ reserves has already been suggested to stabilise commodity prices [5] and the European Union (EU) has identified phosphate rock and P as two of the 27 critical raw materials of high importance to the EU economy and of high risk associated with their supply [6].

As an alternative to mined phosphate rock, organic waste and waste water are renewable sources of $\mathrm{P}$, typically available at the local scale. The P present in these waste streams is chemically or organically bound-i.e., forming complex molecules—or dissolved as orthophosphate. The recovery of $\mathrm{P}$ from secondary streams and its subsequent reuse, either directly or after intermediate processing, represent a major opportunity for exploiting new and more sustainable pathways for producing $\mathrm{P}$ fertilisers. Phosphorus has no substitute but can be reused continuously, and thus, it is a good example of a critical resource that can be utilised more efficiently in the circular economy framework to support sustainable growth with less pollution [7]. Methods potentially applicable for P recovery from waste water and organic waste have been reviewed elsewhere [8-10].

Among the procedures allowing for P recovery from waste streams, chemically induced crystallisation/precipitation/mineralisation of the already dissolved phosphate in the form of low soluble salts is one of the most common alternatives. Precipitation is achieved by appropriately supplying metal ions to the liquid phase, typically magnesium $\left(\mathrm{Mg}^{2+}\right)$, to form magnesium phosphate minerals (MgP) [11-13]; calcium $\left(\mathrm{Ca}^{2+}\right)$ to form calcium phosphate minerals (CaP) [14,15]; or iron $\left(\mathrm{Fe}^{2+}\right)$ to form iron phosphate minerals (FeP) [16-20]. In waste water treatment plants (WWTPs), this kind of process can be implemented at different locations $[9,21]$ in order to foster resource recovery by producing a specific P-rich stream while meeting water quality standards of the receiving water bodies. Additionally, these processes may also involve additional benefits linked to overall plant performance and energy balance such as: (1) prevention of uncontrolled formation of scale deposits in pipelines and recirculation pumps [22-25]; (2) improvement in sludge dewaterability, allowing for producing a dryer solid product, which is advantageous from the point of view of subsequent transport and thermal processing [26,27]; (3) reduction in P backflows [27,28].

Biological $\mathrm{N}$ removal (BNR) is typically applied to reduce the ammonium $\left(\mathrm{NH}_{4}{ }^{+}\right)$content in waste water through its transference to the atmosphere as dinitrogen gas $\left(\mathrm{N}_{2}\right)$. Origin of the waste water-either from municipal, industrial or agricultural sources-will determine its composition, and thus, treatment particularities. In this context, treatment based on the combination of autotrophic nitrification-aerobic oxidation of ammonium to nitrite $\left(\mathrm{NO}_{2}{ }^{-}\right)$(i.e., nitritation), and subsequently, to nitrate $\left(\mathrm{NO}_{3}{ }^{-}\right)$(i.e., nitratation) - , plus heterotrophic denitrification-anoxic reduction of nitrate to nitrite, and finally, to $\mathrm{N}_{2}(\mathrm{NDN})$ - , has commonly been considered. In recent years, the fully autotrophic treatment, based on the combination of partial nitritation (i.e., 57\%) and anaerobic ammonium oxidation (anammox) (PNA), is attracting the interest of the water industry as a more energy-efficient strategy $[29,30]$. Hence, the number of new PNA facilities operating worldwide is increasing fast [31,32]. Some encouraging reasons are the lower energy demand for aeration in partial nitritation and there being no need for an organic $C$ source in anammox (which favours its integration with the anaerobic digestion process to produce biogas as a renewable energy source). Alternatively, nitrification can be applied individually in view of converting ammonium to nitrate, thereby mitigating ammonia $\left(\mathrm{NH}_{3}\right)$ emission from storage facilities and enabling $\mathrm{N}$ recovery from high loaded waste water streams $[33,34]$. Other biological $\mathrm{N}$ treatment processes based on its assimilation and immobilisation and aiming at the recovery of $\mathrm{N}$ products, such as single cell proteins, amino acids, and protein-rich aquaculture plants (e.g., duckweed and algae), are out of the scope of this work.

Phosphate precipitation can be applied before (upstream configuration), together with (concomitant configuration), and after (downstream configuration) biological $\mathrm{N}$ treatment; this is chemically induced as a conditioning pre-treatment, biologically induced inside the reactor, and chemically induced as a refining post-treatment. The aim of this contribution is to perform a detailed 
review of the available alternatives for $\mathrm{P}$ recovery from waste water flows when biological $\mathrm{N}$ treatment is coupled with phosphate precipitation in view of producing materials easily usable as green fertilisers. Particular attention is given to the analysis of the implications of the sequence in which biological treatment and phosphate precipitation are combined. The potential requirements to be complied by the recovered P-rich materials in order to be covered by the EU fertiliser regulation will also be overviewed.

\section{Research Framework}

The scientific literature has been reviewed on the basis of publications appearing in journals indexed in the database Science Citation Index Expanded (SCIE), which was accessed via the Web of Science Core Collection (Clarivate Analytics, Philadelphia, PA, USA). The trend on research productivity is shown in Figure 1, after defining a multi-term topic search including relevant words for the core element under study (e.g., phosphorus, phosphate), the management strategy to be applied (e.g., recovery, recycling), the technological process to be used (e.g., precipitation, crystallisation), the product formed (e.g., struvite, apatite), and the by-products to be processed (e.g., sewage, digestate, urine). Those publications out of our scope (e.g., medical studies, alternative P management strategies), but accidently retrieved, were mostly discarded using automatic filters. The full list of words included in the multi-term topic search, or discarded, are provided as Supplementary Material. Clearly, there is an upward trend in the number of publications that appeared, which is in line with the case study previously reported by Magrí [35], particularly focusing on phosphate precipitation from anaerobic digestates. Following this procedure, the total number of publications retrieved for the last 50 years (1970-2019) was 3050, with about 68,400 citations and an h-index of 107 (accessed on 10 January 2020). According to the growing interest in P recovery from waste streams, some critical literature reviews and comparative technology assessments were recently published. These papers analyse issues such as the principles of phosphate crystallisation, the by-product sources being processed, laboratory feasibility studies, available technologies at pilot- and full-scale, complementary pre-treatments, related environmental and economic aspects, remaining challenges to be addressed, and fertilising properties of the recovered products $[10,12,13,15,36-44]$. As a complementary approach, this paper focuses on the analysis of alternatives for coupling biological $\mathrm{N}$ treatment and phosphate precipitation when processing waste water, while giving some insights about the potential needs for the subsequent use of the recovered phosphate products as P fertilisers.

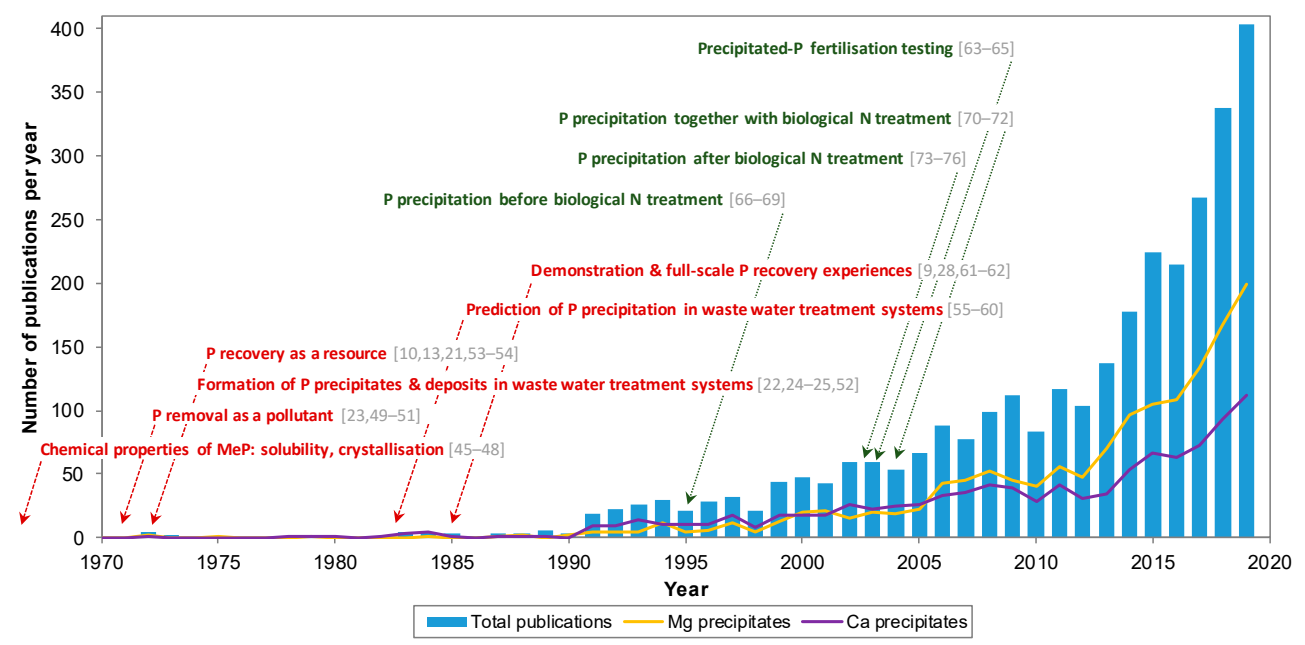

Figure 1. Trend on the number of published papers related to mineral phosphate precipitation from waste water (Source: Web of Science; Accessed: January 10th 2020). Comments indicate meaningful topics and papers $[9,10,13,21-25,28,45-76]$ in this research field (the main topics reviewed in this work are shown in green colour). 


\section{Forms of Mineral Phosphate Precipitates in Waste Water Treatment}

Phosphate recovery from waste water through crystallisation and precipitation is commonly achieved by inducing the formation of $\mathrm{MgP}$ or $\mathrm{CaP}$ mineral forms (Table 1). Moreover, in recent years, $\mathrm{P}$ recovery as $\mathrm{FeP}$ (via crystallisation, not flocculation) has also received considerable attention. Phosphate crystal formation follows two consecutive steps-nucleation (crystal birth) and development of the crystals in the bulk liquid until reaching equilibrium (crystal growth). Control of these stages may be complex, as it involves considering a combination of factors, including the crystal state in waste water, thermodynamics of liquid-solid equilibrium, mass transfer between solid and liquid phases, reaction kinetics, and physicochemical parameters such as temperature, $\mathrm{pH}$, mixing energy, supersaturation, and the presence of foreign ions [12]. Particle size is an important characteristic of the end product obtained. If fine particles represent a significant fraction of the solids formed, this may negatively impact on the soluble phosphate uptake efficiency [77] as well as on the quality of the recovered product in view of its subsequent valorisation [78].

Orthophosphates $\left(\mathrm{PO}_{4}\right)$ can be ionised in multiple groups, including from acidic to basic conditions, phosphoric acid $\left(\mathrm{H}_{3} \mathrm{PO}_{4}\right)$, dihydrogen phosphate ion $\left(\mathrm{H}_{2} \mathrm{PO}_{4}{ }^{-}\right)$, hydrogen phosphate ion $\left(\mathrm{HPO}_{4}{ }^{2-}\right)$, and phosphate ion $\left(\mathrm{PO}_{4}{ }^{3-}\right)$, depending on the $\mathrm{pH}$ as well as on the temperature and ionic strength of the aqueous solution [11] (Figure 2a). In general terms, phosphate precipitation is only possible in supersaturated solutions. Supersaturation causes spontaneous nucleation, and in such circumstances, crystallisation is expected to be fast and abundant, without the need for seeding material addition. It occurs when the saturation index (SI), which is typically calculated as shown in Equation (1) [60], reaches positive values. In such equation, IAP stands for the ionic activity product and $K_{s p}$ is the solubility product constant at the given temperature $\left(\mathrm{p} K_{s p}=-\log _{10} K_{s p}\right)$. The ionic activity of the species " $i$ ", $\{i\}$, is correlated with its molar concentration, $[i]$, according to the corresponding activity factor $\left(\{i\}=\gamma_{i} \cdot[i]\right)$. In turn, this coefficient depends on the ionic charge and the ionic strength of the medium, as described elsewhere $[11,48,56,57]$. As far as the medium becomes diluted, the $\gamma_{i}$ coefficient approaches 1 . The SI provides a non-linear scale for supersaturation. Yet, $S I>0$ is not sufficient for precipitation, since an activation energy barrier prevents the ions to aggregate as crystals. The activation energy can be surmounted by a high $S I$ and presence of nucleation seeds, such as pre-existing crystals or foreign bodies and surfaces. After nucleation, the crystals further increase in size and form particles by aggregation, coagulation, and crystal growth [79].

$$
S I=\log _{10} I A P-\log _{10} K_{s p}
$$

The $\mathrm{MgP}$ are most frequently precipitated as magnesium-ammonium-phosphate hexahydrate (MAP, struvite) $\left[\mathrm{MgNH}_{4} \mathrm{PO}_{4} \cdot 6 \mathrm{H}_{2} \mathrm{O}\right]$ at $\mathrm{pH}$ above neutrality [37]. Although potassium $\left(\mathrm{K}^{+}\right)$can replace $\mathrm{NH}_{4}{ }^{+}$, leading to the formation of magnesium-potassium-phosphate hexahydrate (MPP, K-struvite) $\left[\mathrm{MgKPO}_{4} \cdot 6 \mathrm{H}_{2} \mathrm{O}\right][46,47,80]$, the simultaneous availability of $\mathrm{NH}_{4}{ }^{+}$and $\mathrm{K}^{+}$constrains the precipitation of MPP [81]. Magnesium-hydrogen-phosphate trihydrate (newberyite) $\left[\mathrm{MgHPO}_{4} \cdot 3 \mathrm{H}_{2} \mathrm{O}\right][82,83]$ and trimagnesium phosphate octahydrate (bobierrite) $\left[\mathrm{Mg}_{3}\left(\mathrm{PO}_{4}\right)_{2} \cdot 8 \mathrm{H}_{2} \mathrm{O}\right]$ are also likely to precipitate at some point [58] (Figure 2b). In the case of $\mathrm{CaP}$, the range of possible compounds is even wider [84]. Usual phases involve hydroxyapatite (HAP) $\left[\mathrm{Ca}_{10}\left(\mathrm{PO}_{4}\right)_{6}(\mathrm{OH})_{2}\right]$, tricalcium phosphate (TCP) $\left[\mathrm{Ca}_{3}\left(\mathrm{PO}_{4}\right)_{2}\right]$, amorphous calcium phosphate (ACP) $\left[\mathrm{Ca}_{3}\left(\mathrm{PO}_{4}\right)_{2} \cdot x \mathrm{H}_{2} \mathrm{O}\right]$ - similar to TCP, but with no structured crystalline order-, octacalcium phosphate (OCP) $\left[\mathrm{Ca}_{8} \mathrm{H}_{2}\left(\mathrm{PO}_{4}\right)_{6} \cdot 5 \mathrm{H}_{2} \mathrm{O}\right]$, dicalcium phosphate anhydrous (DCPA, monenite) $\left[\mathrm{CaHPO}_{4}\right]$, and dicalcium phosphate dihydrate (DCPD, brushite) $\left[\mathrm{CaHPO}_{4} \cdot 2 \mathrm{H}_{2} \mathrm{O}\right]$ (Figure 2c). In this group, HAP $[45,85]$ is preferentially formed, under neutral or basic conditions, as the most thermodynamically stable and insoluble mineral phase. However, HAP precipitation is a rather slow phenomenon. Thus, transient formation of intermediate phases-i.e., metastable states but exhibiting a faster formation rate such as DCPD (this is the most soluble phase of all those referred above), $\mathrm{OCP}$, and ACP—is also feasible. Subsequently, these precursors may slowly transform into HAP [86,87]. Co-precipitation of different mineral forms involving $\mathrm{MgP}$ and $\mathrm{CaP}$ is a common issue depending on 
waste water composition and the operational conditions applied [88]. Finally, the typical FeP formed in WWTPs is ferrous iron phosphate (vivianite) $\left[\mathrm{Fe}_{3}\left(\mathrm{PO}_{4}\right)_{2} \cdot 8 \mathrm{H}_{2} \mathrm{O}\right]$, mostly in anaerobic systems with relatively low sulphide concentrations when iron and phosphate are available [17].

Table 1. Main phases of interest regarding magnesium phosphates ( $\mathrm{MgP})$, calcium phosphates $(\mathrm{CaP})$, and iron phosphates $(\mathrm{FeP})$ when applying mineral precipitation aimed at phosphorus recovery in waste water treatment. Me, metal- $\mathrm{Mg}$, Ca or Fe.

\begin{tabular}{|c|c|c|c|c|c|c|}
\hline Name & $\begin{array}{l}\text { Empirical } \\
\text { Formula }\end{array}$ & $\begin{array}{c}\text { Molecular } \\
\text { Weight (g/mol) }\end{array}$ & $\begin{array}{l}\text { P Content } \\
(w t \%)\end{array}$ & $\begin{array}{c}\text { Me/P Molar } \\
\text { Ratio }\end{array}$ & $\begin{array}{l}\text { pKsp } \\
\left(25^{\circ} \mathrm{C}\right)\end{array}$ & Requirements \\
\hline \multicolumn{7}{|l|}{ MgP minerals } \\
\hline $\begin{array}{c}\text { Magnesium } \\
\text { ammonium } \\
\text { phosphate (MAP, } \\
\text { struvite) }\end{array}$ & $\mathrm{MgNH}_{4} \mathrm{PO}_{4} \cdot 6 \mathrm{H}_{2} \mathrm{O}$ & 245.41 & 12.62 & 1.00 & $13.26^{1}$ & $\begin{array}{l}\mathrm{pH}>7 ; \mathrm{Mg} / \mathrm{Ca} \\
\text { molar ratio }>0.6\end{array}$ \\
\hline $\begin{array}{c}\text { Magnesium } \\
\text { potassium } \\
\text { phosphate (MPP, } \\
\text { K-struvite) }\end{array}$ & $\mathrm{MgKPO}_{4} \cdot 6 \mathrm{H}_{2} \mathrm{O}$ & 266.47 & 11.62 & 1.00 & $11.68^{2}$ & $\begin{array}{c}\mathrm{NH}_{4}^{+} \\
\text {unavailable }\end{array}$ \\
\hline $\begin{array}{l}\text { Magnesium } \\
\text { hydrogen } \\
\text { phosphate } \\
\text { trihydrate } \\
\text { (newberyite) }\end{array}$ & $\mathrm{MgHPO}_{4} \cdot 3 \mathrm{H}_{2} \mathrm{O}$ & 174.33 & 17.77 & 1.00 & $5.51^{3}$ & Acid $\mathrm{pH}$ values \\
\hline $\begin{array}{l}\text { Trimagnesium } \\
\text { phosphate } \\
\text { octahydrate } \\
\text { (bobierrite) }\end{array}$ & $\mathrm{Mg}_{3}\left(\mathrm{PO}_{4}\right)_{2} \cdot 8 \mathrm{H}_{2} \mathrm{O}$ & 406.98 & 15.22 & 1.50 & $25.20^{4}$ & Basic $\mathrm{pH}$ values \\
\hline \multicolumn{7}{|l|}{ CaP minerals } \\
\hline $\begin{array}{l}\text { Hydroxyapatite } \\
\text { (HAP) }\end{array}$ & $\mathrm{Ca}_{10}\left(\mathrm{PO}_{4}\right)_{6}(\mathrm{OH})_{2}$ & 1004.6 & 18.50 & 1.67 & $116.8^{5}$ & $\begin{array}{l}\text { Long timescale } \\
\text { (ripening of } \\
\text { precursors); Low } \\
\mathrm{Mg} / \mathrm{Ca} \text { ratio }\end{array}$ \\
\hline $\begin{array}{c}\text { Tricalcium } \\
\text { phosphate }(\alpha-\mathrm{TCP} \\
\text { and } \beta \text {-TCP })\end{array}$ & $\mathrm{Ca}_{3}\left(\mathrm{PO}_{4}\right)_{2}$ & 310.18 & 19.97 & 1.50 & $\begin{array}{l}25.5(\alpha) \\
28.9(\beta)^{5}\end{array}$ & - \\
\hline $\begin{array}{c}\text { Amorphous } \\
\text { calcium } \\
\text { phosphate }(\mathrm{ACP})\end{array}$ & $\mathrm{Ca}_{\mathrm{x}}\left(\mathrm{PO}_{4}\right)_{\mathrm{y}} \cdot n \mathrm{H}_{2} \mathrm{O}$ & * & * & * & * & $\begin{array}{c}\text { Lack of } \\
\text { crystallisation } \\
\text { nuclei }\end{array}$ \\
\hline $\begin{array}{c}\text { Octacalcium } \\
\text { phosphate (OCP) }\end{array}$ & $\mathrm{Ca}_{8} \mathrm{H}_{2}\left(\mathrm{PO}_{4}\right)_{6} \cdot 5 \mathrm{H}_{2} \mathrm{O}$ & 982.53 & 18.91 & 1.33 & $96.6^{5}$ & - \\
\hline $\begin{array}{c}\text { Dicalcium } \\
\text { phosphate (DCPA, } \\
\text { monenite) }\end{array}$ & $\mathrm{CaHPO}_{4}$ & 136.06 & 22.76 & 1.00 & $6.90^{5}$ & Acid $\mathrm{pH}$ values \\
\hline $\begin{array}{c}\text { Dicalcium } \\
\text { phosphate } \\
\text { dihydrate (DCPD, } \\
\text { brushite) }\end{array}$ & $\mathrm{CaHPO}_{4} \cdot 2 \mathrm{H}_{2} \mathrm{O}$ & 172.09 & 18.00 & 1.00 & $6.59^{5}$ & Acid $\mathrm{pH}$ values \\
\hline \multicolumn{7}{|l|}{ FeP minerals } \\
\hline $\begin{array}{l}\text { Ferrous iron } \\
\text { phosphate } \\
\text { (vivianite) }\end{array}$ & $\mathrm{Fe}_{3}\left(\mathrm{PO}_{4}\right)_{2} \cdot 8 \mathrm{H}_{2} \mathrm{O}$ & 501.61 & 12.35 & 1.50 & $36.0^{6}$ & $\begin{array}{c}\text { Stimulated by Fe } \\
\text { dosage }\end{array}$ \\
\hline
\end{tabular}




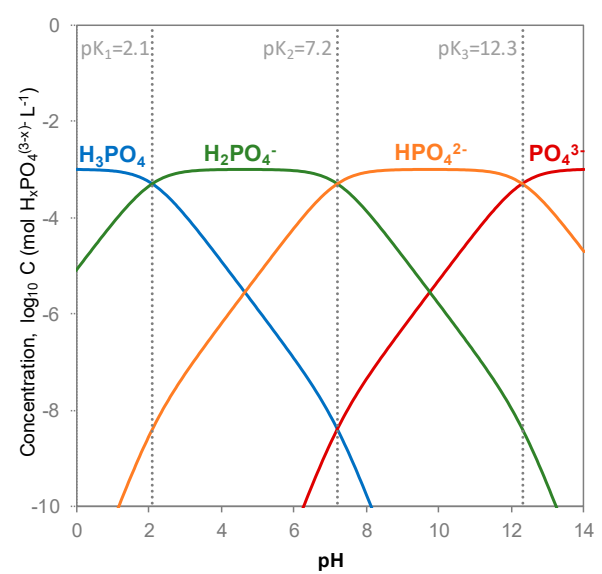

(a)

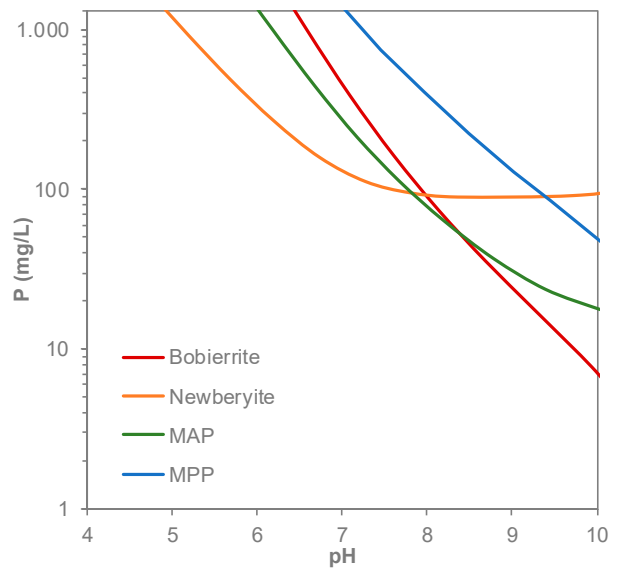

(b)

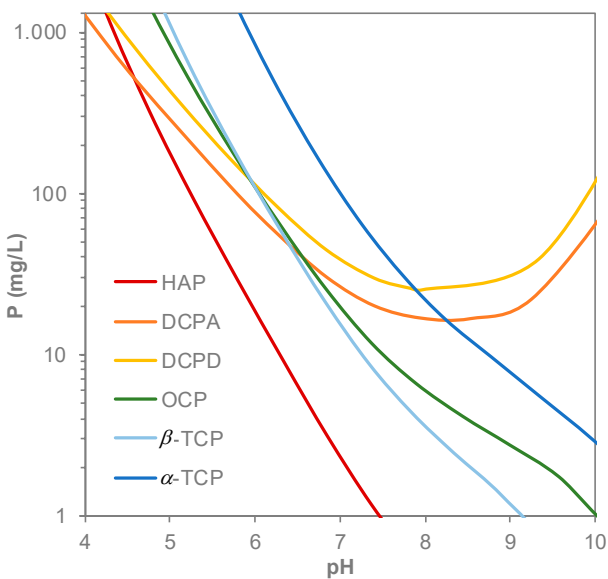

(c)

Figure 2. (a) Top:Logarithmic concentration diagram for phosphoric acid $\left(1 \mathrm{mM}, 25^{\circ} \mathrm{C}\right)$; Soluble orthophosphate concentration in water as a function of $\mathrm{pH}$ at the equilibrium, according to the solubility isotherms of: (b) Middle: the magnesium phosphate $(\mathrm{MgP})$ phases in the $\mathrm{Mg}(\mathrm{OH})_{2}-\mathrm{X}-\mathrm{H}_{3} \mathrm{PO}_{4}-\mathrm{H}_{2} \mathrm{O}$ system at $25^{\circ} \mathrm{C}$. The component $\mathrm{X}$ is only considered for MAP as $\mathrm{NH}_{3}$, and for MPP as $\mathrm{K}(\mathrm{OH})$, and equimolarly to $\mathrm{Mg}(\mathrm{OH})_{2}$ in both cases. Values for the $\mathrm{X} / \mathrm{Mg}$ molar ratio higher than 1 will favour precipitation of the solid phase; (c) Bottom:the calcium phosphate $(\mathrm{CaP})$ phase in the $\mathrm{Ca}(\mathrm{OH})_{2}-\mathrm{H}_{3} \mathrm{PO}_{4}-\mathrm{H}_{2} \mathrm{O}$ system at $25^{\circ} \mathrm{C}$. At $\mathrm{pH}$ values above 4.5 , $\mathrm{HAP}$ is the most stable phase. At lower $\mathrm{pH}$ values, DCPA is more stable than HAP. Calculations made using Visual MINTEQ [60]. 


\section{Linking Phosphorus Recovery to Biological Nitrogen Treatment}

Mineral phosphate precipitation from waste water can be applied before, together with, and after biological $\mathrm{N}$ treatment (Figure 3). In engineered systems for BNR (this refers to both NDN and PNA processes), an initial nitrification is typically required [29,91]. This aerobic process (in particular, nitritation, which is the first step of nitrification involving ammonium conversion into nitrite) entails proton release (ca. $2.0 \mathrm{~mol} \mathrm{H}^{+} \mathrm{mol}^{-1}$ oxidised- $\mathrm{NH}_{4}{ }^{+}$), and consequently, it causes reduction in $\mathrm{pH}$ as well as degradation of alkalinity and buffer capacity-mostly due to the decrease in the total inorganic carbon content (TIC; this is the carbonate system: $\mathrm{H}_{2} \mathrm{CO}_{3}{ }^{*}+\mathrm{HCO}_{3}{ }^{-}+\mathrm{CO}_{3}{ }^{2-}$ ). Air sparging, eventually related to the supply of oxygen for nitrification, will also favour dissolved carbon dioxide $\left(\mathrm{CO}_{2}\right)$ stripping [92,93]. Oppositely, both heterotrophic denitrification and anammox imply proton consumption (ca. $1.0 \mathrm{~mol} \mathrm{H}^{+} \mathrm{mol}^{-1}$ reduced- $\mathrm{NO}_{3}{ }^{-}$and $0.13 \mathrm{~mol} \mathrm{H}^{+}$mol $^{-1}$ oxidised- $\mathrm{NH}_{4}{ }^{+}$, respectively). Hence, these two processes promote a rise in the $\mathrm{pH}$ value and provide alkalinity to the bulk liquid, even though in a lesser extent than has already been consumed in the previous step (final proton release range approximately is $1.0-1.2 \mathrm{~mol} \mathrm{H}^{+}$ $\mathrm{mol}^{-1}$ removed-N as $\mathrm{N}_{2}$ ). In addition, the transformation of the ammonium into $\mathrm{N}_{2}$ will imply a decrease in the ionic strength of the medium - loss of salinity—favouring mineral precipitation due to a higher effective concentration of the ions involved. Since phosphate precipitation typically requires increasing $\mathrm{pH}$, the collateral effects of BNR treatments, such as the reduction in the buffering capacity, ionic strength and soluble $\mathrm{CO}_{2}$ content, will allow for a reduced dosage of chemicals to the water flow, involving significant cost savings in process operation for concomitant or downstream precipitation layouts.

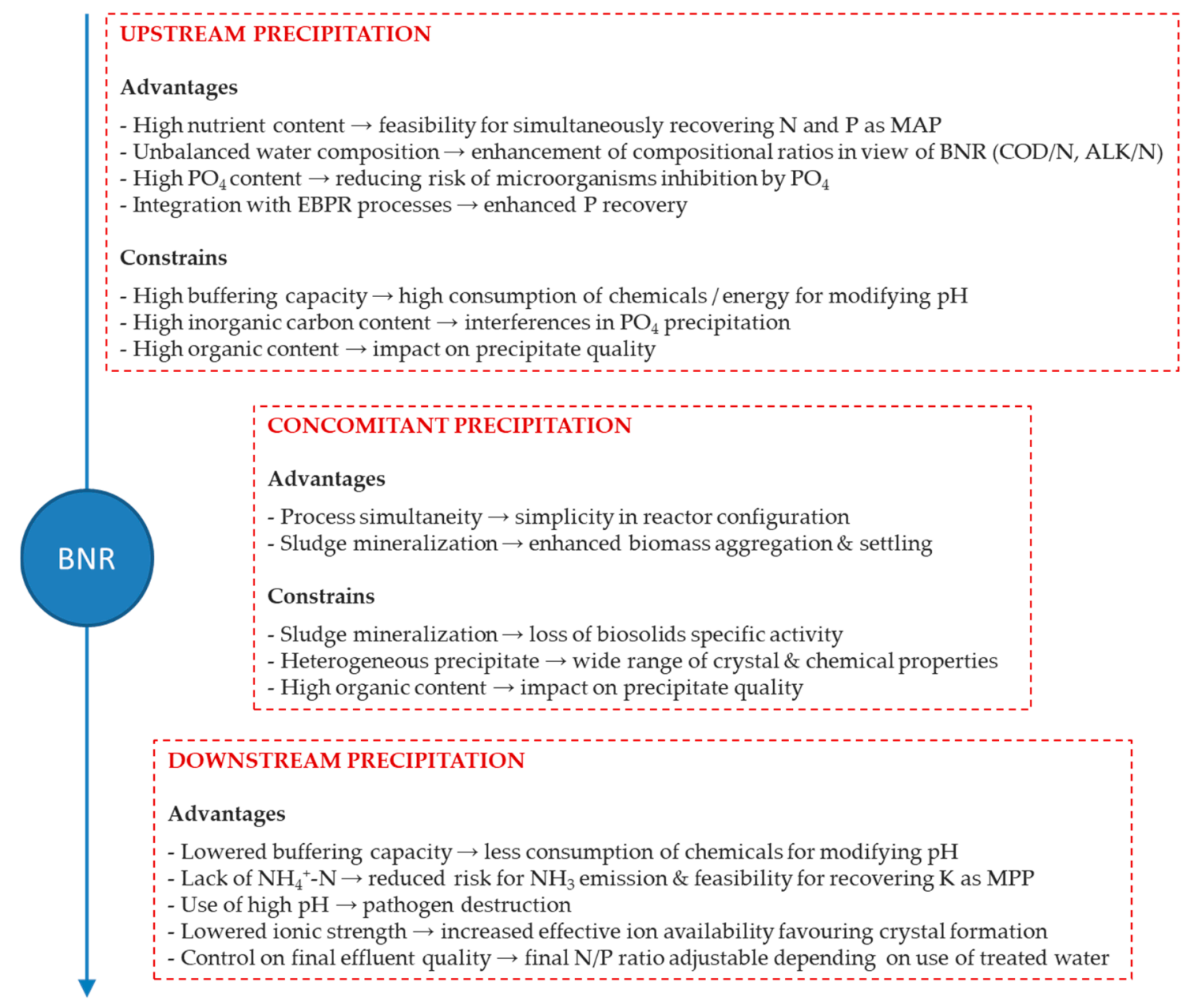

Figure 3. Advantages and constraints for recovering $\mathrm{P}$ by precipitation depending on the location of the process in relation to biological $\mathrm{N}$ treatment (upstream, concomitant or downstream precipitation). 
In municipal WWTPs performing nutrient removal (Figure 4), NDN is typically used in the mainstream (large flow of low loaded waste water), whereas PNA can more robustly be applied in the side-stream following anaerobically digested sludge dewatering (small flow of warm, i.e., $15-35^{\circ} \mathrm{C}$, high loaded waste water). This internal liquid stream-named as centrate when obtained by centrifugation-contributes only about $2 \%$ of the total influent flow entering the plant, but contains $10-30 \%$ of the total $\mathrm{N}$ and $\mathrm{P}$ load $[27,94,95]$. Particular treatment of the centrate rather than its recirculation to the headworks of the treatment plant favours optimised configurations in terms of energy-efficiency, cost-effectiveness, and sustainability [94]. The application of precipitation technologies in facilities equipped for chemical P removal in the mainstream-mostly using Fe and aluminium (Al) salts as flocculants $[49,50]$ - may entail a reduced recovery potential due to limited availability of the salt-forming ions at the equilibrium [16]. Yet, sludge digestion triggers orthophosphate release, especially when running at thermophilic conditions [96]. Hence, the implementation of enhanced biological P removal (EBPR), or chemical P removal using iron, in the mainstream, commonly results in the accumulation of phosphate in the centrate [16]. Chemical P removal is preferred over EBPR when stringent limits are enforced. Phosphorus entering the treatment plant but not recoverable from the centrate will partly be contained in the treated effluent (ca. 20\%) and partly in the digested dewatered sludge (ca. $50-70 \%$ ). According to van der Kooij et al. [97], optimised phosphate precipitation from centrate in WWTPs would result in recovery efficiencies of 3-8\% of all $\mathrm{P}$ excreted by humans. Otherwise, according to the World Health Organization, only about one-third of the global population is served by sewered sanitation and could conceivably benefit from the resource recovery options stated here.

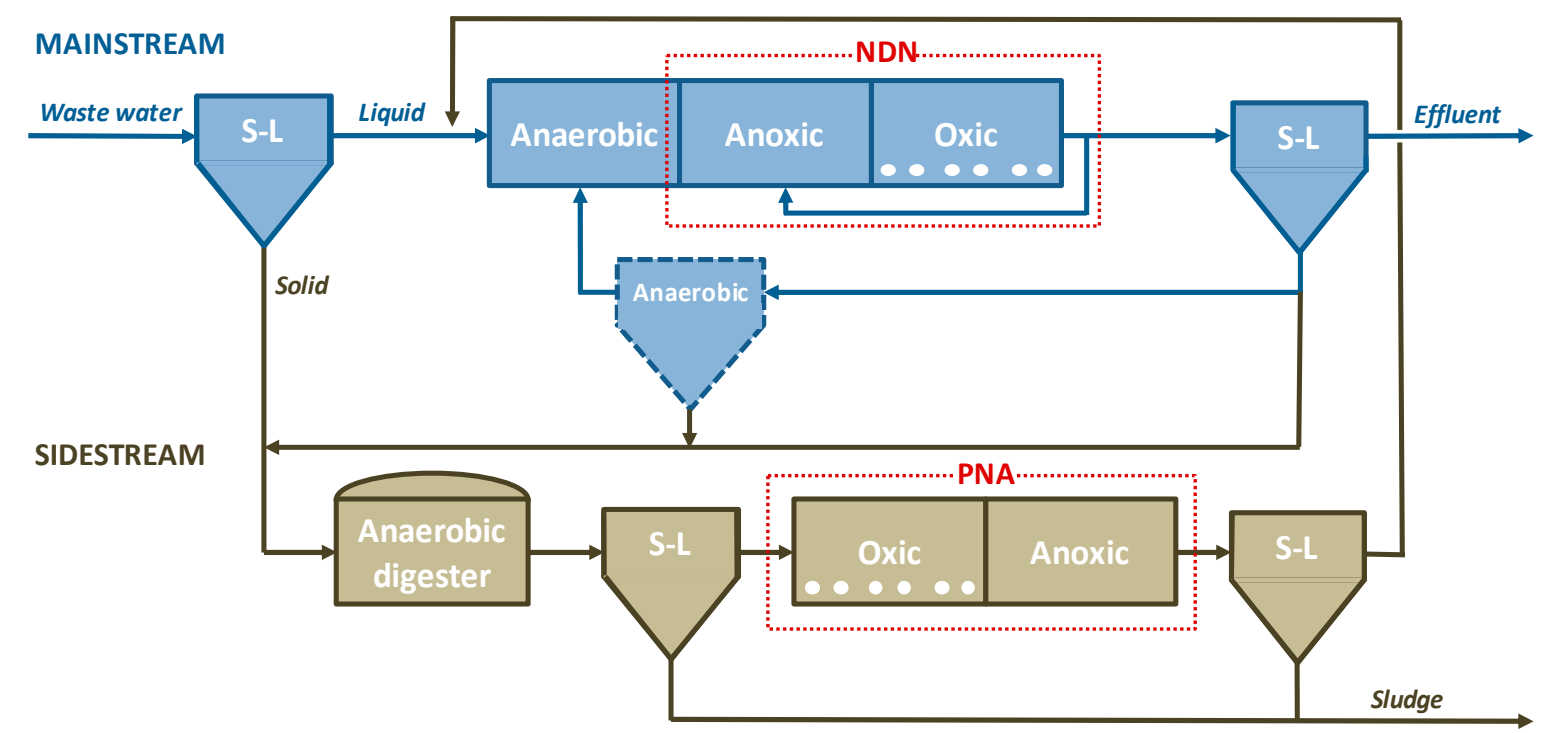

Figure 4. Example of layout for a biological waste water treatment system including the main- and side-stream. Potentially, $\mathrm{P}$ recovery by precipitation can be performed before, together with, or after $\mathrm{N}$ removal (it concerns bioprocesses such as NDN and PNA). Particular schemes will vary depending on the specificities of the treatment to be applied.

Alternative layouts for biologically treating $\mathrm{N}$ from waste water are feasible by modifying the scheme shown in Figure 4. This is particularly applicable when waste water comes from sources other than municipal (e.g., industrial or agricultural).

$\mathrm{MgP}$ precipitation as MAP allows for the simultaneous recovery of $\mathrm{P}$ and $\mathrm{N}$ (struvite theoretically contains $12.6 \% \mathrm{P}, 5.7 \% \mathrm{~N}$ and $9.9 \% \mathrm{Mg}$ on a dry weight basis-as well as $44 \%$ crystal water-which is equivalent to ratios of $0.45 \mathrm{~g} \mathrm{~N} \mathrm{~g}^{-1} \mathrm{P}$ and $7.9 \mathrm{~g} \mathrm{MAP} \mathrm{g}^{-1} \mathrm{P}$ ). Hence, it interestingly involves $\mathrm{N}$ recovery rather than its removal. Yet, $\mathrm{P}$ is usually present in waste water at lower concentrations than $\mathrm{N}$, so $\mathrm{N}$ is recovered at a low efficiency, mostly remaining in the water line entering the bioreactor (e.g., frequently, waste water contains more than $4.5 \mathrm{~g} \mathrm{~N} \mathrm{~g}^{-1} \mathrm{P}$, so maximum potential for $\mathrm{N}$ recovery as MAP is less 
than $10 \%$ ). Alternatively, CaP precipitation as HAP involves formation of a mineral with a higher $\mathrm{P}$ content (HAP theoretically contains $18.5 \% \mathrm{P}$ and $39.8 \% \mathrm{Ca}$ on a dry weight basis, which is equivalent to $\left.5.4 \mathrm{~g} \mathrm{HAP} \mathrm{g}^{-1} \mathrm{P}\right)$. Once formed, phosphate precipitates can be settled, dewatered, and dried in view of favouring transport. A holistic approach is needed when integrating chemical and biological processes for waste water treatment, since the modification of the $\mathrm{pH}$ to favour mineral precipitation may result in unappropriated $\mathrm{pH}$ and/or lack of alkalinity for the subsequent biological $\mathrm{N}$ treatment. Recently, Shaddel et al. [98] suggested that the adaptation of the precipitated product to the physicochemical properties of the targeted waste water would allow improving of the value chain for the recovered $\mathrm{P}$ - e.g., $\mathrm{CaP}$ and MgP can be precipitated at different locations within the same treatment facility, depending on $\mathrm{NH}_{4}{ }^{+}$availability.

Overall, the recovery potential when using precipitation technologies is low, typically 10-15\% [27,99], and maximum $30-40 \%[36,100]$ of the $\mathrm{P}$ load in the influent stream, the rest remaining in the biosolids. Economic feasibility for $\mathrm{P}$ recovery will depend on its content in the liquid phase, with threshold levels close to $50 \mathrm{mg} \mathrm{PO}_{4}-\mathrm{P} \mathrm{L}^{-1}$ [21]. In this regard, final implementation of $\mathrm{P}$ recovery by precipitation may include the use of preliminary mobilisation-dissolution procedures [36,101]. Although the modest recovery potential mentioned above seems to offer a limited contribution to resolve global $\mathrm{P}$ shortage issues, at the local scale, it may help in creating new opportunities in more sustainable communities and protecting the environment while reducing treatment costs [102].

\subsection{Phosphorus Recovery before Biological N Treatment (Upstream Configuration)}

Integrative waste water treatment alternatives, considering P-recovery by chemical precipitation before biological N oxidation or removal, have conceptually been analysed under different scenarios [103,104] and also experimentally studied [66-69,105-122], as summarised in Table 2 (an extended version of this table is provided as Supplementary Material).

Table 2. Summary of experiences integrating chemical precipitation aimed at $\mathrm{P}$ recovery, followed by biological $\mathrm{N}$ oxidation, or removal (upstream precipitation). More details are given as Supplementary Material.

\begin{tabular}{|c|c|c|c|c|}
\hline Waste Water Source & $\begin{array}{l}\text { Precipitation } \\
\text { Performance }\end{array}$ & $\begin{array}{l}\text { Bioprocess } \\
\text { Performance }\end{array}$ & $\begin{array}{c}\text { Precipitate } \\
\text { Characteristics }\end{array}$ & Reference \\
\hline \multicolumn{5}{|c|}{ NDN as the bioprocess following chemical P precipitation } \\
\hline Hydrolysed urine & $\begin{array}{l}\text { MgP precipitated in lab } \\
\text { tests simultaneously to } \\
\text { vacuum thermal } \\
\text { stripping at } 25-65^{\circ} \mathrm{C} \text { by } \\
\text { adding } \mathrm{MgCl}_{2}\end{array}$ & $\begin{array}{c}\text { NDN via nitrite; } \\
\text { Increased COD/N and } \\
\mathrm{ALK} / \mathrm{NH}_{4}{ }^{+}-\mathrm{N} \text { mass } \\
\text { ratios after } \\
\text { precipitation } \\
\text { favoured NDN }\end{array}$ & $\begin{array}{l}\text { MgP mostly precipitated } \\
\text { as MAP; Composition of } \\
\text { the precipitate: } 13.1 \% \mathrm{P} \\
\quad 8.2 \% \mathrm{Mg}, 5.3 \% \mathrm{~N}\end{array}$ & {$[68]$} \\
\hline $\begin{array}{c}\text { Anaerobically digested } \\
\text { sludge dewatering } \\
\text { centrate from a } \\
\text { municipal WWTP }\end{array}$ & $\begin{array}{l}\mathrm{MgP} \text { precipitated in a lab } \\
\text { batch reactor by adding } \\
\qquad \mathrm{MgCl}_{2}\end{array}$ & $\begin{array}{l}\text { Nitrification in a } \\
\text { fixed-film reactor, } \\
\text { denitrification in a } \\
\text { MFC-cathode; } \\
\text { MFC-anode fed with } \\
\text { raw waste water }\end{array}$ & $\begin{array}{l}\text { No data available for the } \\
\text { precipitate }\end{array}$ & {$[105]$} \\
\hline
\end{tabular}


Table 2. Cont.

\begin{tabular}{|c|c|c|c|c|}
\hline Waste Water Source & $\begin{array}{l}\text { Precipitation } \\
\text { Performance }\end{array}$ & $\begin{array}{l}\text { Bioprocess } \\
\text { Performance }\end{array}$ & $\begin{array}{c}\text { Precipitate } \\
\text { Characteristics }\end{array}$ & Reference \\
\hline $\begin{array}{c}\text { Side-stream sludge } \\
\text { fermenter effluent from } \\
\text { an EBPR system treating } \\
\text { low-strength synthetic } \\
\text { waste water }\end{array}$ & $\begin{array}{c}\text { CaP precipitated in a } \\
\text { SBR by adding } \mathrm{Ca}(\mathrm{OH})_{2}\end{array}$ & $\begin{array}{l}\text { EBPR in a continuous } \\
\text { flow-activated sludge } \\
\text { system; Fermentation } \\
\text { of purged sludge + } \\
\text { precipitation of } \\
\text { released } P \text { lead to } \\
\text { improved P uptake } \\
\text { and } N \text { removal in the } \\
\text { mainstream }\end{array}$ & $\begin{array}{l}\text { Composition of the } \\
\text { precipitate: } 13.8 \% \mathrm{P}\end{array}$ & [107] \\
\hline Urine & $\begin{array}{l}\mathrm{PO}_{4} \text { precipitated in a lab } \\
\text { stirred system using } \mathrm{RO} \\
\text { brine (from a reclaimed } \\
\text { WWTP in a thermal } \\
\text { power plant) as metal } \\
\text { ions source }\end{array}$ & $\begin{array}{l}\text { NDN via nitrite in a } \\
\text { continuous } \\
\text { flow-activated sludge } \\
\text { system using an } \\
\text { internal/external } \\
\text { COD source }\end{array}$ & $\begin{array}{l}\text { Precipitates produced at } \\
\text { different brine/urine } \\
\text { mixture ratios with } \\
10-15 \% \text { P; The amount of } \\
\text { brine added affected } \mathrm{Mg} \\
\text { or Ca in the solid; No } \\
\text { presence of hazardous } \\
\text { compounds }\end{array}$ & {$[108]$} \\
\hline $\begin{array}{l}\text { Ultrafiltered permeate } \\
\text { from an(aerobically) } \\
\text { digested sludge } \\
\text { dewatering centrate in a } \\
\text { municipal WWTP }\end{array}$ & $\begin{array}{l}\text { MgP precipitated in lab } \\
\text { batch tests; } \mathrm{Mg} / \mathrm{NH}_{4} / \mathrm{PO}_{4} \\
\text { adjusted with } \mathrm{MgCl}_{2}+ \\
\mathrm{K}_{2} \mathrm{HPO}_{4} ; \text { Use of } \\
\text { seeding material }\end{array}$ & $\begin{array}{l}\text { NDN in a continuous } \\
\text { flow-activated sludge } \\
\text { system for treating raw } \\
\text { sewage plus MgP } \\
\text { precipitation effluent; } \\
\text { Mixing of precipitation } \\
\text { effluent with raw } \\
\text { sewage decreased } \\
\text { COD and N } \\
\text { removal efficiency }\end{array}$ & $\begin{array}{l}\text { MgP precipitated mostly } \\
\text { as MAP; Quality of the } \\
\text { MgP precipitated } \\
\text { potentially compromised } \\
\text { by the heavy } \\
\text { metals content }\end{array}$ & [109] \\
\hline $\begin{array}{l}\text { Low-strength synthetic } \\
\text { waste water }\end{array}$ & $\begin{array}{c}\text { MgP precipitated in a } \\
\text { lab FBR }\end{array}$ & $\begin{array}{c}\mathrm{NDN} \text { in a MBR } \\
\text { intermittently aerated; } \\
\text { P-recovery in FBR } \\
\text { enhanced SND and } \\
\mathrm{COD}, \mathrm{NH}_{4}^{+} \text {and } \mathrm{PO}_{4} \\
\text { removal in } \mathrm{MBR}\end{array}$ & $\begin{array}{c}\text { MgP precipitate mostly } \\
\text { as MAP }\end{array}$ & {$[111]$} \\
\hline $\begin{array}{l}\text { Low-strength synthetic } \\
\text { waste water }\end{array}$ & $\begin{array}{l}\mathrm{CaP} \text { precipitated in a lab } \\
\text { upflow reactor; } \mathrm{CaCl}_{2} \\
\text { added after the anaerobic } \\
\text { stage of an EBPR system } \\
\text { and } \mathrm{CO}_{2} \text { stripping by } \\
\text { aeration; Calcite as } \\
\text { seeding material }\end{array}$ & $\begin{array}{l}\text { EBPR in a continuous } \\
\text { flow-activated sludge } \\
\text { system for } \mathrm{N} \text { and } \mathrm{P} \\
\text { removal; Chemical } \mathrm{P} \\
\text { precipitation } \\
\text { favoured EBPR }\end{array}$ & $\begin{array}{c}\text { CaP precipitate mostly } \\
\text { as HAP (or precursors); } \\
\text { Composition of the } \\
\text { precipitate: } 8-13 \% \mathrm{P} ; \\
\text { Carbonate } \\
\text { co-precipitation }\end{array}$ & {$[112,113]$} \\
\hline $\begin{array}{c}\text { Side-stream sludge } \\
\text { fermenter effluent from } \\
\text { an EBPR system treating } \\
\text { low-strength synthetic } \\
\text { waste water }\end{array}$ & $\begin{array}{l}\text { MgP precipitated in } \\
\text { batch by adding } \mathrm{MgO}\end{array}$ & $\begin{array}{l}\text { EBPR in an SBR also } \\
\text { involved partial N } \\
\text { removal through NDN; } \\
\text { Fermentation of } \\
\text { purged sludge } \\
\text { followed by } \\
\text { precipitation of the } \\
\text { released N and P lead } \\
\text { to higher P separation } \\
\text { efficiency and } \\
\text { complete nitrification }\end{array}$ & $\begin{array}{c}\text { MgP precipitate mostly } \\
\text { as MAP }\end{array}$ & {$[114]$} \\
\hline
\end{tabular}


Table 2. Cont.

\begin{tabular}{|c|c|c|c|c|}
\hline Waste Water Source & $\begin{array}{l}\text { Precipitation } \\
\text { Performance }\end{array}$ & $\begin{array}{c}\text { Bioprocess } \\
\text { Performance }\end{array}$ & $\begin{array}{c}\text { Precipitate } \\
\text { Characteristics }\end{array}$ & Reference \\
\hline Swine waste water & $\begin{array}{l}\text { MgP precipitated in a lab } \\
\text { CSTR; Precipitate } \\
\text { recovered from an } \\
\text { external settler; } \mathrm{MgP} \\
\text { precipitate partly } \\
\text { recycled to the reaction } \\
\text { tank as seeding material }\end{array}$ & $\begin{array}{l}\text { NDN in a 2-stage } \\
\text { continuous flow } \\
\text { activated sludge } \\
\text { system (+ settler); } \\
\text { COD/TN mass ratio } \\
\text { increased favouring } \\
\text { NDN, COD/TP mass } \\
\text { ratio increased } \\
\text { favouring EBPR }\end{array}$ & $\begin{array}{c}\text { MgP precipitate partly as } \\
\text { MAP; Anhydrous } \\
\text { precipitate with } 25.3 \% \mathrm{P}, \\
18.3 \% \mathrm{Mg}, 7.1 \% \mathrm{~N}, 5.4 \% \\
\mathrm{~K}, 2.5 \% \mathrm{Ca} \text {; Quality of } \\
\text { the precipitate } \\
\text { potentially compromised } \\
\text { by the organic content }\end{array}$ & [115] \\
\hline $\begin{array}{l}\text { Anaerobically digested } \\
\text { landfill leachate }\end{array}$ & $\begin{array}{l}\text { MgP precipitated in a lab } \\
\text { stirred system using } \\
\mathrm{MgCl}_{2} \text { and } \mathrm{PO}_{4}\end{array}$ & $\begin{array}{l}\mathrm{NDN} \text { in an } \mathrm{SBR} ; \\
\mathrm{BOD}_{5} / \mathrm{NH}_{4}^{+}-\mathrm{N} \text { mass } \\
\text { ratio increased } \\
\text { favouring } \mathrm{NDN} ; \mathrm{The} \\
\text { higher } \mathrm{MgCl}_{2} \text { addition } \\
\text { the higher } \mathrm{NH}_{4}^{+} \\
\text {separation as } \mathrm{MAP} ; \\
\text { High } \mathrm{Cl}^{-} \text {could limit } \\
\text { nitrification }\end{array}$ & $\begin{array}{l}\text { Composition of the } \mathrm{MgP} \\
\text { formed not determined } \\
\text { analytically }\end{array}$ & [116] \\
\hline $\begin{array}{l}\text { Rare-earth smelting } \\
\text { waste water }\end{array}$ & $\begin{array}{c}\mathrm{MgP} \text { precipitated in lab } \\
\text { batch tests; } \mathrm{Mg} / \mathrm{NH}_{4} / \mathrm{PO}_{4} \\
\text { adjusted with } \mathrm{MgSO}_{4}+ \\
\mathrm{Na}_{2} \mathrm{HPO}_{4} \text { (among other } \\
\text { P-sources) }\end{array}$ & $\begin{array}{l}\text { SND in a batch system } \\
\text { using immobilised } \\
\text { microorganisms; } \\
\text { COD/NH }{ }_{4}^{+}-\mathrm{N} \text { mass } \\
\text { ratio increased } \\
\text { favouring NDN; Rare } \\
\text { metal ions removed } \\
\text { from the liquid phase } \\
\text { favouring biological } \\
\text { treatment }\end{array}$ & $\begin{array}{l}\text { MgP precipitate mostly } \\
\text { assumed as } \mathrm{MAP} ; \\
\text { Composition: } 15.6 \% \mathrm{P} \\
9.3 \% \mathrm{~N}, 8.3 \% \mathrm{Mg} \\
\text { Quality of the } \mathrm{MgP} \\
\text { precipitated } \\
\text { compromised by the rare } \\
\text { metal content }\end{array}$ & [117] \\
\hline $\begin{array}{l}\text { Raw swine waste water } \\
\text { obtained by } \\
\text { centrifugation }\end{array}$ & $\begin{array}{c}\mathrm{MgP} \text { precipitated in lab } \\
\text { batch tests; } \mathrm{Mg} / \mathrm{NH}_{4} / \mathrm{PO}_{4} \\
\text { adjusted with } \mathrm{MgCl}_{2}+ \\
\mathrm{KH}_{2} \mathrm{PO}_{4}\end{array}$ & $\begin{array}{l}\mathrm{NDN} \text { in a } \\
\text { fill-and-draw system } \\
\text { under intermittent } \\
\text { aeration; } \mathrm{BOD} / \mathrm{TN} \\
\text { increased enhancing } \\
\mathrm{NDN} \text {; Additional } \mathrm{PO}_{4} \\
\text { precipitated as } \mathrm{CaP} \text { by } \\
\text { adding } \mathrm{CaCl}_{2} \text { once } \\
\text { biotreatment ended }\end{array}$ & $\begin{array}{l}\text { Composition of the } \mathrm{MgP} \\
\text { not determined } \\
\text { analytically }\end{array}$ & {$[66,118]$} \\
\hline \multicolumn{5}{|c|}{$P N A$ as the bioprocess following chemical $P$ precipitation } \\
\hline $\begin{array}{l}\text { Digester sludge } \\
\text { thickening lagoon } \\
\text { supernatant in a } \\
\text { municipal WWTP }\end{array}$ & $\begin{array}{l}\text { MAP precipitated by the } \\
\text { Ostara }{ }^{\circledR} \text { process at } \\
\text { full-scale }\end{array}$ & $\begin{array}{l}\text { PNA in an IFAS-SBR } \\
\text { with intermittent } \\
\text { aeration; High } \mathrm{PO}_{4} \\
\text { inhibited anammox } \\
\text { bacteria; Higher } \\
\text { tolerance to } \mathrm{PO}_{4} \text { stress } \\
\text { when biomass grew as } \\
\text { biofilm rather than } \\
\text { forming flocs }\end{array}$ & $\begin{array}{l}\text { No data available for the } \\
\text { precipitate }\end{array}$ & [69] \\
\hline $\begin{array}{l}\text { Anaerobically digested } \\
\text { sludge dewatering } \\
\text { centrate in a } \\
\text { municipal WWTP }\end{array}$ & $\begin{array}{l}\text { MgP precipitated in a lab } \\
\text { CSTR with } \mathrm{MgO}\end{array}$ & $\begin{array}{l}\text { PNA as 2-step process } \\
\left(\mathrm{PO}_{4} \text { precipitated after }\right. \\
\mathrm{PN} \text { ) and also as 1-step } \\
\text { process (with } \\
\text { intermittent aeration) } \\
\text { using SBRs }\end{array}$ & $\begin{array}{l}\text { Composition of the } \mathrm{MgP} \\
\text { formed not determined } \\
\text { analytically }\end{array}$ & [119] \\
\hline $\begin{array}{c}\text { Anaerobically digested } \\
\text { industrial (potato) } \\
\text { waste water }\end{array}$ & $\begin{array}{l}\mathrm{MgP} \text { precipitated in a lab } \\
\text { mixed reactor with } \\
\mathrm{MgCl}_{2} ; \text { Urea added to } \\
\text { the crystallisator } \\
\text { as } \mathrm{N} \text { source }\end{array}$ & $\begin{array}{l}\text { PNA as 2-step process } \\
\text { (CSTR w/o sludge } \\
\text { retention + UFBR) and } \\
\text { also as 1-step } \\
\text { process (UFBR) }\end{array}$ & $\begin{array}{l}\text { MgP precipitate mostly } \\
\text { as MAP }\end{array}$ & [120] \\
\hline
\end{tabular}


Table 2. Cont.

\begin{tabular}{|c|c|c|c|c|}
\hline Waste Water Source & $\begin{array}{l}\text { Precipitation } \\
\text { Performance }\end{array}$ & $\begin{array}{l}\text { Bioprocess } \\
\text { Performance }\end{array}$ & $\begin{array}{c}\text { Precipitate } \\
\text { Characteristics }\end{array}$ & Reference \\
\hline $\begin{array}{l}\text { Anaerobically digested } \\
\text { industrial (potato) waste } \\
\text { water from a UASB } \\
\text { reactor + anaerobically } \\
\text { digested sludge } \\
\text { dewatering centrate in a } \\
\text { municipal WWTP }\end{array}$ & $\begin{array}{l}\text { MAP precipitated by the } \\
\text { PHOSPAQ }{ }^{\mathrm{TM}} \text { process at } \\
\text { full-scale, aeration } \\
\text { supplied for bCOD } \\
\text { degradation and } \mathrm{CO}_{2} \\
\text { stripping; } \mathrm{MgO} \text { dosed as } \\
\text { Mg source }\end{array}$ & $\begin{array}{l}\text { PNA as 1-step process } \\
\text { with granular sludge } \\
\text { and dynamically } \\
\text { controlled continuous } \\
\text { aeration at } 37^{\circ} \mathrm{C}\end{array}$ & $\begin{array}{l}\text { MAP with low heavy } \\
\text { metals content with } \\
\text { respect to EU standards } \\
\text { for fertilisers; Precipitate } \\
\text { fertilising effectiveness } \\
\text { demonstrated in } \\
\text { field tests }\end{array}$ & {$[121,122]$} \\
\hline $\begin{array}{c}\text { Anaerobically } \\
\text { co-digested sludge } \\
\text { dewatering supernatant } \\
\text { in a municipal WWTP }\end{array}$ & $\begin{array}{c}\text { MgP precipitated in a } \\
\text { CSTR using } \mathrm{MgCl}_{2} \\
\text { or } \mathrm{MgCO}_{3}\end{array}$ & $\begin{array}{c}\text { PNA as 2-step process: } \\
\text { MBBR + SBR; } \mathrm{PO}_{4}-\mathrm{P} \\
\text { increase implied } \\
\text { specific anammox } \\
\text { activity loss }\end{array}$ & $\begin{array}{l}\text { Composition of the MgP } \\
\text { formed not determined } \\
\text { analytically }\end{array}$ & {$[67]$} \\
\hline
\end{tabular}

Chemically induced phosphate precipitation before BNR from waste water-and also in the case of not considering BNR-typically requires to increase the $\mathrm{pH}$ (preferably above 8.0-8.5) by dosing an alkaline reagent (e.g., sodium hydroxide, $\mathrm{NaOH}$ ) or by applying $\mathrm{CO}_{2}$ stripping $[93,123]$, and to adjust the amount of alkaline-earth metal ions (i.e., $\mathrm{Mg}^{2+}$ or $\mathrm{Ca}^{2+}$ ) available to effective concentrations according to the accessible phosphate-typically slightly above the theoretically needed ratios. The chemicals commonly used as precipitant agents are oxides $(\mathrm{MgO}, \mathrm{CaO})$, hydroxides $\left(\mathrm{Mg}(\mathrm{OH})_{2}, \mathrm{Ca}(\mathrm{OH})_{2}\right)$, and soluble salts (e.g., $\mathrm{MgCl}_{2}, \mathrm{CaCl}_{2}$ ) [68,107,122]. Alternatively, low grade renewable sources, including secondary raw materials and by-products [108], or seawater [110], can also be used. Feasibility of their use depends on factors, such as metal compound availability, solubility, and reactivity [39].

The composition of the waste water to be treated will determine the particular operational conditions to be applied and the quality of the recovered product. At high $\mathrm{pH}$, availability of TIC may negatively impact on phosphate precipitation efficiency due to undesired competition for formation of non-phosphated compounds [14,60,124]. In this regard, Song et al. [14] reported experimental work showing that at $\mathrm{pH} 8.0$, the phosphate precipitation rate was significantly slowed down (and the phosphate precipitation efficiency decreased) by the presence of carbonates, probably because of the formation of ion pairs between carbonate and $\mathrm{Ca}$, leading to a decrease in free $\mathrm{Ca}^{2+}$ ions. In spite of this fact, at $\mathrm{pH}$ 9.0-11.0, the effect was not so obvious, and carbonate co-precipitated with phosphate, resulting in a decrease in $\mathrm{P}$ content in the precipitate. The presence of solids and organic compounds is expected to negatively affect efficiency of crystallisation and purity of the precipitate $[125,126]$. This factor may introduce some constraints on the handling of the recovered product. Otherwise, precipitation can help adjusting compositional ratios when aiming at treating raw liquid streams. This is, for instance, the case of the $\mathrm{BOD} / \mathrm{N}$ ratio (BOD is biochemical oxygen demand) before applying the NDN process. By considering MAP precipitation as pre-treatment, Maekawa et al. [66], treating raw swine waste water, achieved a rise in the $\mathrm{BOD} / \mathrm{N}$ ratio from 1.6 to $7 \mathrm{~g} \mathrm{O}_{2} \mathrm{~g}^{-1} \mathrm{~N}$ before biological treatment, or similarly, Chen et al. [116], treating digested landfill leachate, increased this ratio from 1.5 to $6.5 \mathrm{~g} \mathrm{O}_{2} \mathrm{~g}^{-1} \mathrm{~N}$ (a minimum value of $5-6 \mathrm{~g} \mathrm{O}_{2} \mathrm{~g}^{-1} \mathrm{~N}$ is needed to ensure complete denitrification, according to Henze et al. [127]). When processing complex industrial waste waters with moderate $\mathrm{N}$ load, such as those produced by the leather tanning industry, the appropriate addition of chemicals for precipitating MAP, together with an optimised management of source separated streams, may allow decreasing the concentration of ammonium to typical levels for urban waste water. In such context, and depending on local regulations, MAP precipitation may allow for direct effluent discharge to the public sewer, making unnecessary biological treatment based on nitrification or NDN. If further biological treatment for chemical oxygen demand (COD) removal was still required, then the remaining ammonium would be mostly uptaken by the heterotrophic organisms growing within the reactor (as a high-rate activated sludge system) $[128,129]$. The high Ca content in this kind of waste water can compromise MAP precipitation, making the dosage of an extra amount of phosphate necessary. The potential valorisation of the precipitate will depend on the content of heavy metals (e.g., chromium), 
or sulphide, among other factors [130]. Alternatively, when MAP valorisation as fertiliser is not feasible, it can still be converted thermally to magnesium-hydrogen-phosphate for its further reuse in the precipitation process. In this conversion, $\mathrm{NH}_{3}$ gas is released [131]. By absorbing this ammonia into a $\mathrm{CO}_{2}$ aqueous solution, an ammonium bicarbonate stream is obtained, which potentially can be treated by PNA [132], among other options.

When processing organic streams, by introducing an acidification step before precipitation, either abiotic [133] or biotic [101], targeting P mobilisation, it is feasible to increase significantly the availability of soluble orthophosphate in the liquid phase, therefore enhancing the potential for recovering $\mathrm{P}$ in the form of mineral precipitate. The presence of suspended particles $\left(1-3 \mathrm{~g} \mathrm{~L}^{-1}\right)$ may favour the aggregation/agglomeration of small phosphate crystals, resulting in bigger crystalline structures [134]. The presence of inorganic impurities in the waste water will also affect the quality (i.e., composition), particle size (i.e., mean, homogeneity), and separation capacity of the precipitated products $[135,136]$.

The precipitation process can be operated in a dedicated reactor where particles are suspended by either the liquid flow rate $[69,111,137]$, upflow circulation of air $[122,138]$ or mechanical stirring $[67,115$, 139]. Although this is the conventional scenario for conducting phosphate precipitation, with several technologies commercially available [9] and being increasingly applied, some shortcomings have also been reported, such as recovery of low-value products, high operational costs, unsatisfactory $\mathrm{P}$ recovery efficiency, complex operating conditions, high energy consumption, and large footprint [18,43]. Additionally, some negative experiences were also reported in the literature concerning phosphate precipitation. As an example, Karakashev et al. [140] tested MAP precipitation within a complex strategy for treating pig manure, which integrated multiple processes. Precipitation was specifically applied to anaerobically digested manure supernatant (obtained by centrifugation). $\mathrm{MgO}$ was added as precipitant agent $\left(30 \%\right.$ overdosed) at $\mathrm{pH} 8.5$ and $30^{\circ} \mathrm{C}$. In such conditions, $96 \% \mathrm{P}$ uptake efficiency was achieved so that some $\mathrm{Mg}$ still remained in the water line. Nitrogen loss due to ammonia stripping was also detected. The availability of residual $\mathrm{Mg}$ negatively affected the biological activity in a subsequent high-rate anaerobic process-i.e., upflow anaerobic sludge blanket (UASB) reactor. Moreover, it also triggered uncontrolled MAP formation within a downstream aerated bioreactor for partially oxidising ammonium to nitrite before an anammox reactor.

High phosphate levels have been reported as inhibitory for some groups of microorganisms involved in N removal processes, especially for the anammox bacteria. Phosphate limiting concentrations may vary widely [141] depending on factors such as bioreactor configuration, biomass aggregation form, and microbial species involved $[142,143]$. As an example, total inhibition sometimes has been described above $155 \mathrm{mg} \mathrm{PO}_{4}-\mathrm{P} \mathrm{L}^{-1}$ [144], whereas in others cases, concentrations as high as $1665 \mathrm{mg} \mathrm{PO}_{4}-\mathrm{P} \mathrm{L}^{-1}$ (which is tenfold higher, much above the range of phosphate concentrations usually found in waste water) only caused 50\% inhibition regarding the maximum anammox activity. Thus, the implementation of a phosphate precipitation step prior to a PNA system aiming to decrease phosphate concentration in the water line can help in optimising bioprocess performance $[69,119]$. Yet, some phosphate should remain available in order to assure biomass growth [145]. Moreover, when culturing anammox granular biomass, phosphate availability can contribute to enhance settleability and other mechanical properties of the granules due to the accumulation of CaP precipitates [146-149].

\subsection{Phosphorus Recovery Together with Biological N Treatment (Concomitant Configuration)}

\subsubsection{Biologically Induced Phosphate Mineralisation}

Biomineralisation is a widespread phenomenon in nature that occurs from the formation of rusty proteins in bacteria to macroscopic structures of shells and bones. More in detail, biologically induced mineralisation involves the precipitation of minerals as a collateral consequence of the reaction between extracellular ions and metabolic products released across or into the cell wall. These minerals are expected to have a heterogeneous range of crystal and chemical properties [150]. The active role of microorganisms, mostly bacteria, inducing biomineralisation of soluble phosphate together with $\mathrm{Mg}^{2+}, \mathrm{Ca}^{2+}$ or $\mathrm{Fe}^{2+}$, 
has already been described amply in natural environments and related laboratory experiments [151-153]. Thus, under appropriate conditions, microbial activity may trigger the formation of extracellular (crystal) aggregates of minerals such as MAP [154-156], bobierrite [157], ACP [158] or HAP [153]. Factors affecting such process include bacterial strain [152,154,158,159], temperature [160], pH [161-163], constituent ion concentration [162-164], salt concentration [159], and agitation [165]. Otherwise, there is still a great potential for improving scientific understanding and developing practical implementations of biologically induced P mineralisation in the field of waste water treatment $[70,166,167]$.

\subsubsection{Phosphorus Recovery Experiences in Concomitant Configuration}

Previous experiences concerning simultaneous biological $\mathrm{N}$ oxidation or removal and biologically induced P precipitation within the same bioreactor in the framework of waste water treatment, aimed at promoting P recovery, are summarised in Table 3 [70-72,168-172] (an extended version of this table is provided as Supplementary Material). This approach allows simplifying the configuration of the treatment system. Promising results have been obtained at lab-scale using different kinds of bioreactors running with suspended, granular or biofilm-type sludge. Operational conditions such as temperature and $\mathrm{pH}$, as well as concentration of constituent ions (e.g., $\mathrm{NH}_{4}{ }^{+}, \mathrm{Mg}^{2+}$, and $\mathrm{Ca}^{2+}$ ), will play a critical role in mineral phosphate formation, mostly as CaP.

Recent works conducted at Tohoku University (Japan) with anammox biomass in expanded bed reactors showed that, using synthetic substrate and under optimised bioreactor operation, simultaneous $\mathrm{N}$ removal and $\mathrm{P}$ uptake were feasible at rates as high as $16.7 \mathrm{~g} \mathrm{~N} \mathrm{Lr}^{-1} \mathrm{~d}^{-1}$ and $1.2 \mathrm{~g} \mathrm{P} \mathrm{Lr}^{-1} \mathrm{~d}^{-1}$ at $25{ }^{\circ} \mathrm{C}$ (by adding $\mathrm{CaCl}_{2}$ in the internal recirculation) [172], or $44.8 \mathrm{~g} \mathrm{~N} \mathrm{Lr}^{-1} \mathrm{~d}^{-1}$ and $0.4 \mathrm{~g} \mathrm{P} \mathrm{Lr}^{-1}$ $\mathrm{d}^{-1}$ at $35^{\circ} \mathrm{C}$ (using inner mineral cores of granules as biofilm carriers) [170]. A highly mineralised sludge grew within these reactors, with a relative volatile content that could fall down to values below $25 \%$ of the dry weight. A composite granule formed by a bacterial biofilm (mostly anammox cells) attached to the inorganic core was observed. Local $\mathrm{pH}$ gradients were reported. The increase in $\mathrm{pH}$ value in the inner part of the granule facilitated the crystallisation of phosphate. Even though reported $\mathrm{N}$ removal efficiencies were high (75-90\%), these values might still be enhanced by integrating a pre-denitritation stage (i.e., $\mathrm{NO}_{3}{ }^{-}$reduced to $\mathrm{NO}_{2}{ }^{-}$) prior to the anammox reactor (an internal recirculation would be needed for such configuration) in order to remove the nitrate formed by the anammox reaction (i.e., anammox reaction involves ca. 10\% $\mathrm{N}$ conversion to nitrate) [173]. Use of mechanically stirred reactors resulted in much lower activities than those mentioned above [70,71]. As an example, Johansson et al. [70] treated anaerobically digested sludge dewatering centrate in a granular sludge sequencing batch reactor (SBR) operating the PNA process at $25{ }^{\circ} \mathrm{C}$ according to loading rates of $0.3 \mathrm{~g} \mathrm{~N} \mathrm{Lr}^{-1} \mathrm{~d}^{-1}$ and $0.02 \mathrm{~g} \mathrm{P} \mathrm{Lr}^{-1} \mathrm{~d}^{-1}$, achieving $66 \% \mathrm{~N}$ removal (no chemicals were added). The accumulation of minerals increased the density of the granules, leading them to settle fast to the bottom of the bioreactor, where they could easily be harvested. Phosphorus content normally is $1-2 \%$ dry weight in normal activated sludge and 5-7\% in P enriched EBPR sludge [174]. By considering the concomitant configuration discussed in this section, values of 10-16\% have typically been reported [70,169,172]. Candidatus Accumulibacter phosphatis, which is commonly found in EBPR systems [175], has also been found in granular PNA systems and identified as potentially responsible for inducing HAP precipitation [176]. Biologically induced MAP production from anaerobic sludge dewatering centrates has also been demonstrated as feasible in preliminary incubation experiments using specifically selected microbial strains (e.g., Bacillus pumilus, Brevibacterium antiquum, Myxococcus xanthus, Halobacterium salinarum, and Idiomarina loihiensis), opening a completely new route for $\mathrm{P}$ recovery via biomineralisation $[166,177,178]$. On this line, biologically mediated MAP (and other MgP together with calcium carbonate) precipitation was also reported in open, mixed-culture, biofilm bioreactors treating low-strength domestic waste water, while potentially responsible microorganisms were isolated for further characterisation (mostly heterotrophic bacteria growing aerobically) $[179,180]$. 
Table 3. Summary of experiences integrating biological $\mathrm{N}$ oxidation, or removal, and mineral precipitation aimed at $\mathrm{P}$ recovery inside the bioreactor (concomitant precipitation). More details are given as Supplementary Material.

\begin{tabular}{|c|c|c|c|c|}
\hline Waste Water Source & $\begin{array}{c}\text { Experimental } \\
\text { Conditions }\end{array}$ & Bioprocess Performance & $\begin{array}{c}\text { Precipitate } \\
\text { Characteristics }\end{array}$ & Reference \\
\hline \multicolumn{5}{|c|}{ Nitrification as the bioprocess concomitant to P precipitation } \\
\hline Synthetic urine & $\begin{array}{l}\text { Long-term nitrification } \\
\text { in trickling filters } \\
\text { partially packed with } \\
\text { pumice and } \\
\text { mussel shells }\end{array}$ & $\begin{array}{l}\mathrm{PO}_{4} \text { precipitation } \\
\text { induced by Ca released } \\
\text { from mussel shells; } \\
\text { Mussel shells also } \\
\text { provided carbonate } \\
\text { needed for buffering } \\
\text { the system }\end{array}$ & $\begin{array}{l}\text { Composition of the } \\
\text { CaP formed not } \\
\text { determined } \\
\text { analytically }\end{array}$ & [168] \\
\hline $\begin{array}{c}\text { Synthetic waste water } \\
\text { mimicking anaerobic } \\
\text { digester } \\
\text { dewatering centrate }\end{array}$ & $\begin{array}{l}\text { PN in aerated SBR vs. } \\
\text { SBBR packed with } \\
\text { polyethylene particles }\end{array}$ & $\begin{array}{c}\text { SBR: faster start-up; } \\
\text { SBBR: more stable facing } \\
\text { disturbances in } \\
\text { dissolved oxygen } \\
\text { conditions }\end{array}$ & $\begin{array}{c}\text { Suspended solids } \\
\text { containing 9-10\% } \mathrm{P} ; \\
\text { Complementary work } \\
\text { [169] in the SBR } \\
\text { transforming PN into } \\
\text { NDN showed that } \mathrm{PO}_{4} \\
\text { precipitated in } \\
\text { different form } \\
\text { depending on } \mathrm{pH}\end{array}$ & [71] \\
\hline \multicolumn{5}{|c|}{ Anammox as the bioprocess concomitant to P precipitation } \\
\hline $\begin{array}{l}\text { Synthetic waste water } \\
\text { mimicking effluent from } \\
\text { a PN reactor }\end{array}$ & $\begin{array}{l}\text { Anammox process in } \\
\text { an EBR with internal } \\
\text { recirculation; Reactor } \\
\text { at } 33^{\circ} \mathrm{C} \text { and pH } 8.6\end{array}$ & 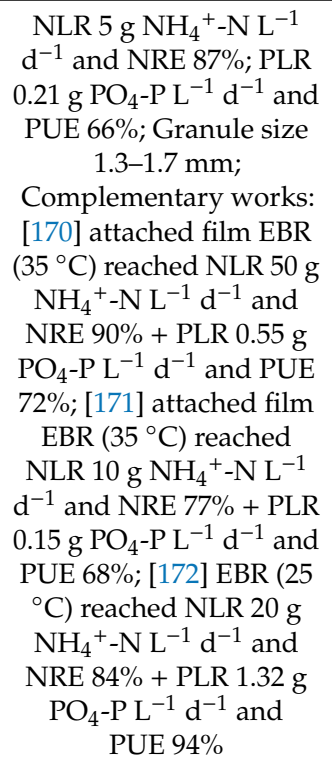 & $\begin{array}{c}\text { CaP recovered as HAP; } \\
\text { Granules with } 83 \% \\
\text { mineral content, } 28.9 \% \\
\mathrm{Ca}, 13.4 \% \mathrm{P}, 0.9 \% \mathrm{~N} \\
0.5 \% \mathrm{Mg}\end{array}$ & [72] \\
\hline \multicolumn{5}{|c|}{ PNA as the bioprocess concomitant to P precipitation } \\
\hline $\begin{array}{l}\text { Anaerobically digested } \\
\text { sludge dewatering } \\
\text { centrate in a municipal } \\
\text { WWTP }\end{array}$ & $\begin{array}{l}\text { PNA process as 1-stage } \\
\text { SBR at } 25^{\circ} \mathrm{C} \text {; No } \\
\text { addition of chemicals } \\
\text { (w/o pH control) }\end{array}$ & $\begin{array}{l}\mathrm{NLR} 0.31 \mathrm{~g} \mathrm{NH}_{4}{ }^{+}-\mathrm{N} \mathrm{L}^{-1} \\
\mathrm{~d}^{-1} \text { and NRE } 66 \%\end{array}$ & $\begin{array}{l}\text { CaP recovered as HAP; } \\
\text { Granules purged with } \\
71 \% \text { ashes, } 33.5 \% \mathrm{Ca} \text {, } \\
\text { 15.8\% P; Heavy metals } \\
\text { complied with EU } \\
\text { standards for P } \\
\text { fertilisers and needs } \\
\text { from } \mathrm{P} \text { industry }\end{array}$ & [70] \\
\hline
\end{tabular}

\subsubsection{Interaction between biological $\mathrm{N}$ treatment processes and soluble phosphate availability}

Beyond waste water composition, the availability of dissolved phosphate in the $\mathrm{N}$ removal bioreactor is highly influenced by the evolution of $\mathrm{pH}$, which drives naturally occurring phosphate precipitation/redissolution phenomena. Dissolved phosphate availability is favoured by acidification (nitrification) [181-183], which may be interesting for promoting its subsequent precipitation as a phosphate salt. Thus, in activated sludge systems, performing BNR with significant co-occurring 
mineral phosphate precipitation, a final step under anoxic conditions (e.g., denitrification), will help in maximising P separation efficiency from the water line, while concentrating $P$ in the sludge $[184,185]$. This phenomenon-CaP precipitation-has also been reported in denitrifying biofilms, where biomass remains attached rather than suspended [52,55]. On the other hand, in the case of co-occurring EBPR within activated sludge bioreactors under alternative anaerobic-anoxic/aerobic conditions due to the metabolism of polyphosphate accumulating organisms (PAOs), microbial phosphate release will be particularly significant during anaerobic periods, eventually leading to co-precipitation events [186-188], or favouring the implementation of alternative configurations aimed at $P$ recovery $[54,174,189,190]$. This can also be significant for new aerobic granular sludge (AGS) systems mostly operated in batches [191,192] and performing simultaneous nitrification-denitrification (SND). The PAOs-which are associated with the formation of dense and compact granules as well as other facultative anaerobic denitrifying bacteria-may become dominant in the core of the granule, and thus, they can play a role in phosphate release under anaerobic conditions, inducing local P precipitation [193-196]. Yet, the overall contribution of this phenomenon in the removal of $\mathrm{P}$ from waste water is conditioned by the re-dissolution of the precipitates under aerobic conditions $[175,181]$ and it may cause instability of the mature granules [197]. Alternatively, anaerobic phosphate release in granular sludge systems may enable the implementation of external P recovery strategies [198]. Metal ions-and particularly, divalent ions such as $\mathrm{Ca}^{2+}$ and $\mathrm{Mg}^{2+}$ needed for phosphate crystallisation-tend to bind to the negatively charged extracellular polymeric substances (EPS) produced by the cells, favouring biomass adhesion and granulation [199]. The nature of the EPS matrix determines which ion is combined. In the case of alginate-like EPS (which are usually produced by AGS), these substances have high affinity for $\mathrm{Ca}^{2+}$ but low affinity for $\mathrm{Mg}^{2+}$, making $\mathrm{Ca}^{2+}$ participate in the formation of the gel structure but $\mathrm{Mg}^{2+}$ only as a counter ion and, consequently, determining which mineral phase is formed. Moreover, $\mathrm{Mg}^{2+}$ and $\mathrm{K}^{+}$play a significant role in maintaining the stability of the EBPR process as phosphate counter ions [200]. Thus, temporal increases in the availability of these ions may induce the development of struvite-like structures onto the AGS-MgP precipitation. Since $\mathrm{NH}_{4}{ }^{+}$is mostly removed by SND, MPP is expected as the main struvite type on the aerobic granules. Yet, when $\mathrm{NH}_{4}{ }^{+}$is available, $\mathrm{NH}_{4}{ }^{+}$adsorption may accompany $\mathrm{K}^{+}$release due to ion exchange [201]. Finally, CaP precipitation and recovery has also been addressed in anaerobic granular reactors targeting biogas production as a renewable energy source [202,203]. Both, carbon source and bulk pH value (7.0-7.5) were identified as key factors for the formation and growth of ACP granules in UASB reactors [204].

\subsection{Phosphorus Recovery after Biological N Treatment (Downstream Configuration)}

Previous experiences reporting $\mathrm{P}$ precipitation after biological $\mathrm{N}$ oxidation or removal are summarised in Table 4 [73-76,99,124,205-210] (an extended version of this table is provided as Supplementary Material). Biological $\mathrm{N}$ treatment based on nitrification involves a reduction in the buffering capacity of the liquid effluent. Denitrification and anammox processes counteract this effect, but only partially, as described in Section 4. Thus, downstream precipitation takes advantage of the high decrease in alkalinity commonly achieved through biological treatment $[74,76]$, resulting in a lesser consumption of chemicals to increase the $\mathrm{pH}$ value $[73,124]$. Moreover, the alkaline environment applied during precipitation may favour sanitation of water by enhancing pathogen destruction $[99,211]$.

High-rate activated sludge systems running with short solids retention times allow for significant COD removal from sewage. The high removal of organic compounds that takes place in these bioreactors is mostly attributed to the adsorption of the colloidal particles onto the suspended solids. Subsequently, such biosolids are separated by settling. According to the operational conditions described above, nitrification does not occur, and ammonium is partially adsorbed, or assimilated, by heterotrophic organisms. Downstream, the ammonium remaining in the biologically treated waste water, together with the orthophosphate available, can simultaneously be precipitated as MAP [129]. 
Alternatively, addition of $\mathrm{Ca}(\mathrm{OH})_{2}$ following high-rate biological treatment has also been suggested to raise $\mathrm{pH}$, favouring ammonia stripping and $\mathrm{CaP}$ precipitation [212].

Table 4. Summary of experiences integrating biological N oxidation, or removal, followed by chemical precipitation aimed at $P$ recovery (downstream precipitation). More details are given as Supplementary Material.

\begin{tabular}{|c|c|c|c|c|}
\hline Waste Water Source & $\begin{array}{l}\text { Bioprocess } \\
\text { Performance }\end{array}$ & $\begin{array}{l}\text { Precipitation } \\
\text { Performance }\end{array}$ & $\begin{array}{c}\text { Precipitate } \\
\text { Characteristics }\end{array}$ & Reference \\
\hline \multicolumn{5}{|c|}{ Nitrification as the bioprocess preceding chemical $P$ precipitation } \\
\hline $\begin{array}{l}\text { Anaerobically digested } \\
\text { swine waste water } \\
\text { from a UASB reactor }\end{array}$ & $\begin{array}{c}\text { Nitrification in a } \\
\text { continuous aerated } \\
\text { system at pilot-scale; } \\
\text { Similar tests also } \\
\text { conducted considering } \\
\text { NDN and PNA as the } \\
\text { bioprocess preceding P } \\
\text { precipitation }\end{array}$ & $\begin{array}{l}\text { CaP precipitated in lab } \\
\text { batch tests using } \\
\text { hydrated lime; Similar } \\
\text { results to those } \\
\text { previously given by [205] }\end{array}$ & $\begin{array}{l}\text { Field tests were also } \\
\text { performed; The sludge } \\
\text { formed contained } 30 \% \\
\mathrm{Ca}, 5.7 \% \mathrm{P}, 2.5 \% \mathrm{Mg} \text {; } \\
\text { The high } \mathrm{Ca} / \mathrm{P} \text { ratio } \\
\text { indicates carbonate } \\
\text { co-precipitation }\end{array}$ & [74] \\
\hline $\begin{array}{c}\text { Anaerobically digested } \\
\text { industrial (potato) } \\
\text { waste water from a } \\
\text { UASB reactor }\end{array}$ & $\begin{array}{l}\text { Nitrification in an } \\
\text { aerated CSTR }\end{array}$ & $\begin{array}{l}\mathrm{CaP} \text { precipitated in a lab } \\
\mathrm{CSTR} \text { with } \mathrm{CaCl}{ }_{2} ; \mathrm{High} \\
\mathrm{pH} \text { and } \mathrm{Ca} / \mathrm{P} \text { triggered } \\
\text { co-precipitation of } \\
\text { carbonates and } \mathrm{MgP} ; \\
\mathrm{Nitrification} \text { reduced } \\
\mathrm{Ca}\left(\mathrm{HCO}_{3}\right)_{2} \text { inhibition } \\
\text { and carbonate } \\
\text { precipitation making } \mathrm{Ca} \\
\text { available for } \mathrm{CaP} \\
\text { precipitation }\end{array}$ & $\begin{array}{c}\mathrm{CaP} \text { precipitated } \\
\text { mostly as HAP; } \\
\mathrm{Ca} \mathrm{P} / \mathrm{Mg} \text { ratio as } \\
1.5 / 1.0 / 0.1\end{array}$ & [206] \\
\hline $\begin{array}{l}\text { Anaerobically digested } \\
\text { industrial (potato) } \\
\text { waste water previously } \\
\text { processed for } \\
\text { urease-induced partial } \\
\text { phosphate removal }\end{array}$ & $\begin{array}{l}\text { Nitrification in an } \\
\text { aerated } \mathrm{MBR} ; \mathrm{Mg} \\
\text { content and } \mathrm{pH} \\
\text { increased due to } \\
\text { preliminary ureolytic } \\
\text { phosphate removal }\end{array}$ & $\begin{array}{l}\text { CaP precipitated in lab } \\
\text { batch tests; Several } \\
\text { chemicals used to raise } \\
\mathrm{pH} \text { and test effect of } \mathrm{TIC} \text {; } \\
\mathrm{TIC} \text { decrease due to } \\
\text { nitrification implied } \\
\text { shorter dosage of } \mathrm{NaOH} \text {; } \\
\mathrm{NaOH} \text { supply w/o } \\
\text { nitrification may lead to } \\
\mathrm{MgP} \text { and } \mathrm{CaCO}_{3} \\
\text { formation; } \mathrm{pH} \text { increase } \\
\text { with } \mathrm{Ca}(\mathrm{OH})_{2} \text { favoured } \\
\mathrm{PO}_{4} \text { precipitation due to } \\
\text { extra Ca dosage; } \mathrm{pH} \\
\text { increase with } \mathrm{Na} \mathrm{CO}_{3} \\
\text { hampered } \mathrm{Ca} \text { and } \mathrm{PO}_{4} \\
\text { precipitation }\end{array}$ & $\begin{array}{l}\text { Composition of the } \\
\text { precipitate not } \\
\text { determined } \\
\text { analytically; Similar } \\
\text { results than in [207] }\end{array}$ & [124] \\
\hline $\begin{array}{l}\text { Surface lagoon liquids } \\
\text { from swine farms }\end{array}$ & $\begin{array}{l}\text { Nitrification in } \\
\text { fluidised bed reactors } \\
\text { with sludge } \\
\text { immobilised in } \\
\text { supporting porous } \\
\text { medium; }>90 \% \text { ALK } \\
\text { reduction and } \\
\text { prevention of } \mathrm{NH}_{3} \\
\text { emission }\end{array}$ & $\begin{array}{l}\text { CaP precipitated in lab } \\
\text { batch tests; } \mathrm{Ca}(\mathrm{OH})_{2} \\
\text { added as precipitant; } \mathrm{pH} \\
\text { increased to } \geq 9.5 \text { for } \\
\text { optimum P precipitation; } \\
\text { Similar field test in [73]; } \\
\mathrm{P} \text { in effluent adjustable } \\
\text { for on-farm use } \\
\text { according to crop needs }\end{array}$ & $\begin{array}{l}\text { Composition of the } \\
\text { precipitate: } 2.5-10 \% \mathrm{P} \text {; } \\
\text { Nitrification favoured } \\
\text { P availability in the } \\
\text { precipitate; The } \\
\text { recovered material can } \\
\text { be exported and } \\
\text { reused as P-fertiliser; } \\
\text { The high pH value } \\
\text { applied in the } \\
\text { precipitation process } \\
\text { destroys pathogens }\end{array}$ & [208] \\
\hline
\end{tabular}


Table 4. Cont.

\begin{tabular}{|c|c|c|c|c|}
\hline Waste Water Source & $\begin{array}{c}\text { Bioprocess } \\
\text { Performance }\end{array}$ & $\begin{array}{l}\text { Precipitation } \\
\text { Performance }\end{array}$ & $\begin{array}{c}\text { Precipitate } \\
\text { Characteristics }\end{array}$ & Reference \\
\hline \multicolumn{5}{|c|}{ NDN as the bioprocess preceding chemical $P$ precipitation } \\
\hline $\begin{array}{l}\text { Fertiliser industry } \\
\text { waste water }\end{array}$ & $\begin{array}{l}\text { NDN in a continuous } \\
\text { flow activated sludge } \\
\text { system at pilot-scale }\end{array}$ & $\begin{array}{c}\mathrm{MgP} \text { precipitated in a } \\
\text { continuous pilot-scale } \\
\text { unit; } \mathrm{Mg} / \mathrm{NH}_{4} / \mathrm{PO}_{4} \\
\text { adjusted with } \mathrm{MgCl}_{2}+ \\
\mathrm{H}_{3} \mathrm{PO}_{4} ; \mathrm{Mg} \text { and } \mathrm{PO}_{4} \\
\text { recovered from the } \\
\text { precipitate by heating } \\
\text { allowing the recycling } \\
\text { within the process }\end{array}$ & $\begin{array}{c}\text { Composition of the } \\
\text { precipitate after drying: } \\
24.0 \% \mathrm{P}, 16.6 \% \mathrm{Mg} \\
1.1 \% \mathrm{~N}\end{array}$ & [209] \\
\hline $\begin{array}{l}\text { Subfloor slurry from a } \\
\text { pig farm, liquid } \\
\text { separated by a rotary } \\
\text { press }\end{array}$ & $\begin{array}{l}\text { NDN in a continuous } \\
\text { flow activated sludge } \\
\text { system at full-scale }\end{array}$ & $\begin{array}{l}\text { CaP precipitated in a } \\
\text { continuous full-scale } \\
\text { unit; Hydrated lime } \\
\text { injected to pH } 9.5\end{array}$ & $\begin{array}{l}\text { Composition of the } \\
\text { precipitate not } \\
\text { determined } \\
\text { analytically; Total } \\
\text { faecal coliforms and } \\
\text { enterococci reduced }\end{array}$ & [99] \\
\hline Calf manure & $\begin{array}{l}\text { NDN running at } \\
\text { full-scale }\end{array}$ & $\begin{array}{l}\text { MPP precipitated in: (1) } \\
\text { lab experiments at room } \\
\text { temperature, (2) pilot } \\
\text { plant running as CSTR, } \\
\text { and (3) full-scale plant ( } 3 \\
\text { CSTRs + settler); MgO } \\
\text { added as Mg source }\end{array}$ & $\begin{array}{l}\text { Lab: Fine-grained } \\
\text { elongated crystals with } \\
\text { a max. diameter of } \\
\text { several tens of microns; } \\
\text { Pilot plant: the } \\
\text { recovered product } \\
\text { contained } 12.5 \% \mathrm{P}, \\
10.7 \% \mathrm{Mg}, 11.4 \% \mathrm{~K} \\
1,3 \% \mathrm{Ca}, 0.7 \% \mathrm{~N}(5.5 \% \\
\text { organic-C) }\end{array}$ & [210] \\
\hline \multicolumn{5}{|c|}{$P N A$ as the bioprocess preceding chemical $P$ precipitation } \\
\hline $\begin{array}{l}\text { Anaerobically digested } \\
\text { sludge dewatering } \\
\text { centrate from two } \\
\text { municipal WWTPs } \\
\text {-with chemical vs. } \\
\text { biological P removal in } \\
\text { the mainstream- }\end{array}$ & $\begin{array}{l}\text { PNA as 1-step process } \\
\text { at lab- and pilot-scale }\end{array}$ & $\begin{array}{l}\text { MgP precipitated in lab } \\
\text { batch tests; } \mathrm{K} \text { uptake } \\
\text { from water line } \\
\text { positively correlated } \\
\text { with pH value up to } 11\end{array}$ & $\begin{array}{c}\text { MgP precipitated as } \\
\text { MAP and MPP; } \\
\text { Precipitate } \\
\text { composition }(\mathrm{pH} 11): \\
11.4 \% \mathrm{P}, 9.2 \% \mathrm{Mg}, 4.3 \% \\
\mathrm{~K}, 3.5 \% \mathrm{~N}, 0.9 \% \mathrm{Ca}\end{array}$ & [76] \\
\hline $\begin{array}{l}\text { Anaerobically digested } \\
\text { manure centrate }\end{array}$ & $\begin{array}{c}\text { After biological } \\
\text { treatment, } \mathrm{Mg} / \mathrm{K} / \mathrm{P} \\
\text { molar ratio adjusted to } \\
\text { ca. } 2.0 / 4.5 / 1.0\end{array}$ & $\begin{array}{l}\text { MgP precipitated in lab } \\
\text { batch tests targeting } \\
\text { MPP recovery; Different } \\
\text { dilutions rates tested to } \\
\text { decrease interference by } \\
\text { TSS }\end{array}$ & $\begin{array}{l}\text { MgP precipitated } \\
\text { mostly as MPP with } \\
\text { co-precipitation of } \\
\text { other salts; Suspended } \\
\text { particles favoured } \\
\text { aggregation of crystals } \\
\text { as star-asterisk forms }\end{array}$ & [75] \\
\hline
\end{tabular}

Lack of ammonium in the $\mathrm{N}$ treated effluents allows raising of $\mathrm{pH}$ for precipitating $\mathrm{MgP}$ without the risk of favouring ammonia emission while recovering other minerals rather than MAP, such as newberyite [213] (which has a specific P content higher than MAP, see Table 1) and MPP (K-struvite) $[75,76]$. Potassium, together with $\mathrm{N}$ and $\mathrm{P}$, is a key macronutrient for plants typically obtained by mining soluble K-salts (potash) [214,215]. Yet, there is growing interest in obtaining K from alternative renewable resources, including waste waters. Optimum $\mathrm{pH}$ for precipitating MPP is higher than for precipitating MAP, within the range 10.5-11.5 [76,216,217]. Successful attempts for simultaneously precipitating $P$ and $K$ have been reported using raw urine [218,219], digested sewage sludge dewatering centrate [76], digested livestock manure centrate [75], and other waste water streams. In the case of $\mathrm{N}$ treated effluents, availability of residual $\mathrm{NH}_{4}{ }^{+}$will trigger simultaneous MAP and MPP formation, resulting in a (N-P-K) multi-nutrient product $[76,210]$. Similarly, the availability of other cations such as sodium $\left(\mathrm{Na}^{+}\right)$will interfere in the precipitation of MPP, thereby reducing $\mathrm{K}$ recovery efficiency [220-222]. The crystal size of the MPP formed is a critical aspect in view of its subsequent use. By optimising process operation parameters related to supersaturation, feeding, 
and mixing, larger crystals can be obtained [223,224]. Moreover, a downstream dewatering step can be advisable to prevent excess of fines in the water line, while improving the agglomeration of the precipitated material [81]. Concerning the liquid effluent, beyond satisfactory discharge into water bodies, ion precipitation can also help adjusting water quality in terms of the N-P-K content to match specific requirements according to the final use (e.g., reuse for crop fertigation) [73].

\section{Use of Recovered Phosphate Products}

The use of the recovered phosphate salts as fertilisers must promote plant growth and nutrient uptake without leading to overall adverse environmental or human health impacts [225]. Recovered $\mathrm{MgP}$ products (i.e., MAP) have been proven as equivalent to regular mineral $\mathrm{P}$ fertilisers and more effective than recovered $\mathrm{CaP}$ products $[63,64]$. Besides, recovered $\mathrm{CaP}$ products are very similar in composition to the mined phosphate rock, so they can be mixed with ores at the beginning of an industrial P production process [226]. Currently, precipitated phosphate salts are not typified in the European fertiliser regulation, and this fact limits marketability.

\subsection{Quality Criteria for the Precipitated Phosphate Salts to be Covered by the EU Fertiliser Regulation}

In the EU, those materials used as fertilisers must comply with the requirements stated by the fertilising products regulation (EU) 2019/1009 [227]. Currently, the precipitated phosphate salts, as well as other derivate products, are not typified as a Component Material Category (CMC) within this regulation. Nonetheless, the topic is in progress. The requirements to be complied by these materials in view of their possible inclusion in an updated version of the rule are overviewed below, according to the criteria fixed by the Joint Research Centre (JRC) of the European Commission [228], who is in charge of establishing a regulatory framework, enabling the production of fertilising products. In this regard, to be accepted as EU fertiliser, the recovered precipitated phosphate salts will have to comply with the requirements laid down for a new CMC "precipitated phosphate salts and derivates" as well as with those for the already stablished Product Function Category (PFC) "1C-Inorganic fertilisers". The newly proposed CMC "precipitated phosphate salts and derivates" aims to cover a wide range of phosphate-based compounds of high purity produced through a precipitation process with the intention to be used as fertilising materials or as intermediates in the manufacturing processes of P-fertilisers, and which are sufficiently effective at providing $\mathrm{P}$ to plants. The technical proposal for the inclusion of precipitated phosphate salts and derivates in the (EU) fertilising products regulation includes the following items: (1) input materials and reagents; (2) production process conditions; (3) agronomic value; (4) environmental and human health aspects; (5) physicochemical properties; (6) handling and storage. As a fertilising product, the use of this material must not lead to overall adverse environmental or human health impacts and must provide plants/mushrooms with nutrients or improve their nutrition efficiency, either on its own or mixed with another material, among other market aspects.

As input materials to the precipitation process, common waste water flows to be taken into account are main- and side-streams in municipal WWTPs and effluents from food processing. Animal manure liquid fractions have also been considered as promising input materials [229]. Concerning the production process, it has been suggested to differentiate between those facilities specifically designed to produce fertilising materials and those others where the precipitated phosphate salts are recovered as a by-product resulting from a process aimed at producing different primary outputs (e.g., energy and treated water), as long as the material quality criteria are fulfilled. The agronomic value of the precipitated phosphate salts has been proposed not to be assessed on the basis of minimum extractable $P$ content (due to misinformation on agronomic efficiency), which is in line with the criterion used for other CMCs. However, it was suggested to label the ratios water-extractable $\mathrm{P}$ to total $\mathrm{P}$, and acid-extractable $P$ to total $P$. Recommended minimum P solubility values are as follows: $25 \%$ in water, $30 \%$ in neutral ammonium citrate, and $35 \%$ in formic acid. 
From the point of view of environmental and human health, and regarding the presence of inorganic, organic, and biological toxic elements, safety must be assured by a combination of requirements in the production process and parameter assessment on the precipitate. Most input materials intended for P recovery through precipitation have high contents of inorganic and organic (micro)pollutants [230], which can be transferred to the precipitate, usually adhered onto organic matter [231,232]. Yet, available data concerning the presence of contaminants in the precipitates, which have often been measured for high-purity precipitated phosphate salts with low organic $C$ content (TOC), tend to indicate safe levels $[228,233]$. To prevent risks associated with particular organic (micro)pollutants (e.g., flame retardants, pharmaceutical compounds), it has been proposed to limit the organic $C$ content in precipitated phosphate salts to a maximum of $3 \%$ of the dry matter content $[228,234]$. By applying satisfactory operational conditions during the production process and considering a maximum threshold for the organic $\mathrm{C}$ content, the risk associated with the accumulation of microbial pathogens in the precipitate will be reduced. In turn, this may help reducing the risk of appearance of microbial resistances in the agrifood chain. Standard microbial testing is proposed, considering as limit values the absence of Salmonella spp. in a $25 \mathrm{~g}$ sample and $1000 \mathrm{CFU} \mathrm{g}$ fresh mass (CFU is colony-forming units) for Escherichia coli or Enterococcus. Additional tests would be required when manure or municipal waste water were used as input material for the production process, ensuring absence of viable Ascaris sp. eggs in a $25 \mathrm{~g}$ fresh mass, and concentrations of Clostridium perfringens (as a spore-forming bacteria) below $100 \mathrm{CFU} \mathrm{g}^{-1}$ fresh mass. Potentially, the precipitated phosphate salts may contain significant levels of trace elements, including heavy metals and metalloids, when such elements are available in the water flows under processing $[235,236]$. When managing biosolids in WWTPs, organic $\mathrm{C}$ has commonly been shown as an important metal-sorption phase [237]. Thus, low organic contents in the precipitate may also help reducing associated metal/metalloid levels. Since typical levels of these contaminants [238] are one or two orders of magnitude below the limit values fixed by the EU fertiliser regulation for the PFC level "inorganic macronutrient fertiliser" [227]-i.e., cadmium (Cd): $60 \mathrm{mg} \mathrm{kg}^{-1} \mathrm{P}_{2} \mathrm{O}_{5}$; chromium (Cr) VI: $2 \mathrm{mg} \mathrm{kg}^{-1}$ dry matter; nickel (Ni): $100 \mathrm{mg} \mathrm{kg}^{-1}$ dry matter; lead (Pb): $120 \mathrm{mg} \mathrm{kg}^{-1}$ dry matter; arsenic (As): $40 \mathrm{mg} \mathrm{kg}^{-1}$ dry matter; copper (Cu): $600 \mathrm{mg} \mathrm{kg}^{-1}$ dry matter; zinc (Zn): $1500 \mathrm{mg} \mathrm{kg}^{-1}$ dry matter-it has not been suggested to include additional specific limit values for metals and metalloids, regardless of the input material.

In relation to the physicochemical properties of the precipitated phosphate salts, the regulation proposals for the new $\mathrm{CMC}$ have mostly concerned on the total $\mathrm{P}$ content, the micronutrients content ( $\mathrm{Al}$ and $\mathrm{Fe}$ ), and the presence of physical impurities. Thus, the precipitated salts have been suggested to have a total $\mathrm{P}$ content of $16 \%\left(\mathrm{P}_{2} \mathrm{O}_{5}\right.$ equivalent) or more, on dry weight basis. According to available data from running plants [228], a $20 \% \mathrm{P}_{2} \mathrm{O}_{5}$ limit value seems an achievable target. Moreover, the assessed material should contain less than $10 \%$ dry matter of Al plus Fe (elemental forms), assuming a Fe/P molar ratio not compromising plant P-availability [239]. Finally, visually detectable physical impurities (above $2 \mathrm{~mm}$ ) should be less than $0.3 \%$ dry matter and total macroscopic impurities less than $0.5 \%$ dry matter, in line with the provisions stablished for other CMCs [227]. As handling and storage conditions, it is proposed to avoid physical contact between input and output materials in the production plant after the precipitation process and to store the precipitated phosphate salts in dry conditions. All the above referred considerations seek to ensure appropriate material quality and chemical composition for the intended functions of the fertilising materials.

\subsection{Expected Characteristics of the Precipitated Phosphate Salts Depending on the Production Process}

Overall, the characteristics of the recovered end-products are strongly dependent on the input material and the precipitation process applied $[88,240]$. Although final decision on the criteria to be fulfilled in order to include precipitated phosphate salts in the EU fertilising products regulation [227] is still pending, characteristics of these materials must be aligned with the abovementioned quality criteria. Thus, the main aspects to be specified will likely be related to the environment, human health, and the physicochemical properties, and focused on features such as the organic $C$ content, toxicity 
limit values (concerning both chemical and biological agents), and particular contents of $\mathrm{P}, \mathrm{Al}, \mathrm{Fe}$, and physical impurities.

When P precipitation is conducted before biological $\mathrm{N}$ treatment (upstream configuration), phosphate is frequently crystallised heterogeneously within a wet sludge. Depending on the waste water source, the resulting product may contain a high amount of impurities including solid particles, organic C-easily above the aforementioned 3\% dry matter-and heavy metals. The availability of organic $\mathrm{C}$ (mostly if biodegradable or not previously digested) will condition the later handling and storage of this P-rich material. Simultaneous phosphate precipitation and biological $\mathrm{N}$ treatment (concomitant configuration) is still under development and not applicable at a large scale, but it is known that this frequently leads to the formation of a heterogeneous precipitate mixed with organic $\mathrm{C}$ (basically, constituted by the microbial cells catalysing the process). Although the nature of this organic $C$ will be different from the case of the upstream configuration, organic contents will be still high. Washing and drying the recovered solids may help in improving their characteristics in view of fitting the requirements needed for a marketable fertiliser product [238]. When $P$ precipitation is applied after biological $\mathrm{N}$ treatment (downstream configuration), the resulting product will have a higher purity and contain less organic C. Risk of chemical and biological toxicity will likely be reduced due to the lower availability of organic matter, potential biodegradation, and adsorption phenomena occurring within the bioreactor and the alkaline environment applied to achieve P precipitation, which will promote pathogens destruction $[99,211]$ (Table 5).

Table 5. Major expected characteristics for the recovered precipitated phosphate salts depending on the production process configuration (upstream, concomitant and downstream alternatives).

\begin{tabular}{cccc}
\hline Characteristics & Upstream & Concomitant & Downstream \\
\hline Purity & $\begin{array}{c}\text { Presence of solids and other } \\
\text { compounds will disturb } \\
\text { crystallisation and affect } \\
\text { purity of precipitate }\end{array}$ & $\begin{array}{c}\text { Heterogeneous } \\
\text { precipitate }\end{array}$ & $\begin{array}{c}\text { Increased effective ion } \\
\text { availability favouring crystal } \\
\text { formation }\end{array}$ \\
\hline Organic content & High & High & Low \\
\hline Toxicity & $\begin{array}{c}\text { Potential presence of metals, } \\
\text { organics and pathogens } \\
\text { depending on the waste } \\
\text { water origin }\end{array}$ & - & $\begin{array}{c}\text { Pathogen destruction } \\
\text { depending on process pH }\end{array}$ \\
\hline P form (most probable) & $\begin{array}{l}\text { MAP and CaP. Carbonate } \\
\text { forms may co-precipitate } \\
\text { together with phosphates }\end{array}$ & CaP and MAP & $\begin{array}{c}\text { Absence of ammonium will } \\
\text { favour formation of alternative } \\
\text { MgP salts such as MPP }\end{array}$ \\
\hline
\end{tabular}

It is important to ensure that any treatment alternative to be implemented at the full-scale will be able to produce valuable materials according the upcoming definition for the CMC "precipitated phosphate salts and derivates". The aim of the EU regulation is to cover a wide range of phosphate-based compounds of high purity, sufficiently effective at providing $\mathrm{P}$ to plants, while reducing the risk of contamination by the long-term application to agricultural soils [241]. Thus, any material that fulfil the proposed quality criteria should be considered. The data summarised in the previous sections of this review indicate the potential occurrence of a wide range of mineral forms in the end-products of the precipitation processes (Table 1). Most of the time, the precipitated P is in the form of struvite, calcium phosphate or a mixture of Ca- and Mg-salts [240]. The form, in which P is combined with other elements to form the precipitated phosphate salts, has a strong effect on the later accessibility to P for plants.

\subsection{Agronomic Efficiency Achieved when Using Precipitated Phosphate Salts}

Plants can only absorb $\mathrm{P}$ if it occurs in specific chemical forms, the most relevant of which is orthophosphate $\left(\mathrm{H}_{2} \mathrm{PO}_{4}{ }^{-}, \mathrm{HPO}_{4}{ }^{2-}\right.$, and $\mathrm{PO}_{4}{ }^{3-}$ as soluble ions). However, in soils, only a small portion of the total $\mathrm{P}$ is available as $\mathrm{PO}_{4}$ dissolved in the soil solution, while the largest amount is bound to 
chemical compounds of different solubility. The amount of P dissolved, and thereby accessible for plant roots during the life cycle of a crop, is defined as plant-available P [242]. Typical relative solubilities for different recycled fertilisers can be found in the literature, referring to the most frequently used extractant chemicals and according to the EU fertiliser regulation [227]. However, the highly variable chemical composition and structure of the P-compounds and other components available in the recycled material, together with its inherent characteristics (e.g., granule size), may affect the solubility in a given extractant chemical $[240,243]$, leading to an unsuitable assessment of the plant-available P. Besides dominant chemical form and structure, soil-plant-fertiliser interactions may also affect $\mathrm{P}$ release dynamics, and availability for crops, depending on: (1) soil properties (e.g., $\mathrm{pH}$, texture, existence of potential P sorption sites); (2) plant characteristics (e.g., plant species, root traits, strategies for mobilising $\mathrm{P}$ from soil, temporary variations in nutrient demand); (3) fertiliser properties (e.g., crystal size, granule size, application method, presence of impurities, occurrence of co-precipitations); (4) type of trial conducted (e.g., properties of the growing substrate, trial duration, pot/field trial, pot size, basic/multi-nutrient supply, weather conditions) [244,245]. Despite such a long list of factors potentially inducing variability when assessing recycled fertilisers' efficiency, there are some common conclusions that can be distilled from the data available in the literature $[64,225,240,245]$. Otherwise, the agronomic efficiency of a fertiliser can be assessed with respect to a reference (or control)-i.e., relative agronomic efficiency (RAE) — on the basis of plant biomass yield (dry matter increase per unit of nutrient supply), or plant nutrient uptake (dry matter yield*biomass nutrient concentration) [246].

The objective for those materials that could be included in the newly proposed CMC "precipitated phosphate salts and derivates" is to supply $\mathrm{P}$ to plants as a macronutrient. Nowadays, precipitated salts, such as (relatively pure) struvite, several forms of $\mathrm{CaP}$, or a mixture of $\mathrm{CaP}+\mathrm{MgP}$, are gaining relevance as a by-product for agronomy. Struvite (MAP) is the most common precipitated phosphate salt, with a high potential to be marketed as a recycled nutrient source since its production is feasible according to a relatively high purity standard (only containing trace amounts of impurities), and also, it has a high P-content and a demonstrated value as a P-fertiliser $[63,64,247]$. Nonetheless, other $\mathrm{CaP}$ and MgP are also registered under the REACH Regulation (Regulation (EC) No 1907/2006) as fertilisers [248]. Constituent molecules and ions, and how they are arranged in the recovered materials, have been proven to influence on the plant-available $P$. In this regard, $P$ will be unavailable for crops if it is strongly bound to certain bi- and trivalent ions. Beyond plant nutrition, this aspect is also relevant because of the potential accumulation of $P$ in soil at the long-term, and social aspects linked to farmer's confidence and market acceptance of innovative $P$ fertilisers derived from secondary raw materials.

Concerning the agronomic efficiency of the struvite as $\mathrm{P}$ fertiliser, published data show variable values for the RAE depending on the origin of the struvite, even when it has been tested under identical growing conditions $[249,250]$. As it has been mentioned above, this is probably because of the presence of co-precipitates and impurities, or the different sizing of crystals and product granules. Nonetheless, good agronomic performance has been reported for a wide range of soil $\mathrm{pH}$ values $[225,245,251]$, even though, in some cases, limited availability of $\mathrm{P}$ was found in basic soils $[244,252]$. It has also been suggested that the high agronomic efficiency of the struvite as P fertiliser is favoured by naturally-occurring local acidifying processes in roots, the uptake of ammonium by the roots, and the nitrification of ammonium to nitrate by the soil microbial community [253-255]. Moreover, several authors did not find significant differences in the RAE for other MgP [63,64,225], showing better $\mathrm{P}$ availability than when considering recycled CaP.

The precipitation of CaP may involve the formation of different compounds. While mono- and di-calcium phosphates show the highest $\mathrm{P}$ availability for plants, the formation of compounds with an increasing Ca content in the binding forms-i.e., with higher values for the $\mathrm{Ca} / \mathrm{P}$ molar ratio-generally results in lower values for $\mathrm{P}$ availability [256]. In addition, the RAE of the CaP varies widely depending on factors such as the aggregation size, crystalline structure, cation content (e.g., $\mathrm{Mg}^{2+}$ ), and presence of co-precipitates [257]. In this regard, several authors have obtained lower values for the RAE of the CaP than for the RAE of other conventional fertilisers, as well as of the struvite $[63,64,225,245,250]$. Generally 
speaking, $\mathrm{CaP}$ tend to show better P availability for plants under (moderately) acidic conditions than under neutral or alkaline conditions, since acidic environments favour the transformation of $P$ into reactive forms $[243,250]$. In calcareous soils, the Ca present in the soil solution will tend to precipitate on the surface of the CaP granules [258]. After soil application, CaP can evolve and transform into more stable mineral phases [259], which could potentially justify the wider range of RAEs observed for $\mathrm{CaP}$ than for struvite and other MgP [225]. According to the current state-of-the-art for technologies that seek to recover $\mathrm{P}$ from waste waters, it is difficult to guide the precipitation processes in a way that the formation of mono- and di-calcium phosphates become dominant [260]. Thus, the CaP commonly formed are unsuitable for most of the soils in Europe, of which $\mathrm{pH}$ value varies between 5 and 8 [261], at least, in the short-term. Regarding FeP, they are not currently registered as fertilisers under the REACH Regulation [248]. Ferric phosphates were initially proposed as end materials to be included in the newly proposed $\mathrm{CMC}$, but finally discarded due to limited testing of the agronomic value (i.e., concerns over the plant availability of Fe-complexed phosphates and risk of $\mathrm{Al} / \mathrm{Fe}$ forms inducing plant toxicity have been reported) [228]. Yet, there may be potential for P recovery from waste water as precipitated FeP mineral salts, which could be used as new input materials or intermediates [16], or as an alternative to other Fe fertilisers used to prevent Fe chlorosis [262].

Indeed, all the precipitated phosphate salts can behave as multi-nutrient fertilisers, since they contain a broad range of elements, including not only $\mathrm{P}$, but also other nutrients for plants. This fact may help justifying the wide range of RAEs reported for these products. Nonetheless, those products recovered as $\mathrm{MgP}$ have been proven to supply equivalent amounts of plant-available $\mathrm{P}$ to other regular, high water-soluble, phosphate rock-based fertilisers, and to be more effective than other products recovered as $\mathrm{CaP}[63,64,225]$. It is challenging to distinguish between effective and ineffective fertilisers due to all the factors influencing nutrient availability and release dynamics. From an agronomic point of view, $\mathrm{MgP}$ (e.g., struvite) are a desirable product due to the higher amount of plant-available $\mathrm{P}$ that they provide and the independence of its dissolution with respect to the soil $\mathrm{pH}$ value. Moreover, those $\mathrm{CaP}$ products recovered as hydroxyapatite are very similar in composition to the mined phosphate rock (i.e., apatite-type ores), so they can be used as feedstock in an industrial $P$ production process $[16,226]$. The use of these secondary raw materials is not expected to result in large discharges of new contaminants into the environment. This scenario contrasts with the current import-based model of phosphate rock-derived P-fertilisers, which is associated with high consumptions of chemicals and new inputs of mobilised metals into the environment. Yet, local conditions should be taken into account in forthcoming scenarios based on closing nutrient cycles, working in close collaboration with all relevant stakeholders, since social and market acceptance of the technologies and recovered products is crucial for their successful implementation [263].

\section{Conclusions}

The recovery of precipitated phosphate salts from waste water may help in reducing dependence on phosphate rock as a critical raw material, while preventing environmental pollution and promoting more sustainable development. Several technological alternatives are feasible for this purpose. The increase in $\mathrm{pH}$ value and the dosage of metal ions (such as $\mathrm{Mg}^{2+}, \mathrm{Ca}^{2+}$, and $\mathrm{Fe}^{2+}$ ) are factors commonly considered. In an integrated approach, the precipitation process can be applied before, during, or after biological $\mathrm{N}$ treatment. Some potential targets are: lowering the consumption of energy and chemical reagents, lowering the treatment cost, minimising the risk of toxicity for the microorganisms involved in the biological treatment, and recovering new valuable and marketable high-quality products in the framework of the circular economy. The typification of the end-products, in order to be covered by the EU fertiliser regulation, is currently ongoing. Phosphorus and organic carbon contents are the primary factors to be taken into account when assessing the characteristics of the precipitated phosphate salts. Those materials fulfilling the technical criteria under discussion will be directly usable as agricultural fertiliser, or as a by-product in the P-fertilisers industry. 


\section{Future Research and Development}

The recovery of phosphates from waste water has been studied for years. Currently, it appears as a relatively easy way to improve the eco-design and sustainability of the WWTPs within the framework of the circular economy model, enabling the production of added-value products that can be recycled as fertilisers. A more frequent implementation of phosphate precipitation technologies at the full-scale for processing different kinds of waste water is expected to push into the development of new distribution channels and a consolidated market for the precipitated salts. Besides municipal and agri-food waste water streams, animal manure liquid phases are also promising as a source of precipitated phosphate salts, since they contain significant amounts of nutrients and specific applications are still scarce. The possibility that certain microorganisms help to produce particular products, either indirectly (e.g., involving EBPR-type processes) or even directly (i.e., inducing biological mineralisation), needs further study and will continue evolving. Moreover, the recovery of alternative products beyond MAP, able to supply $\mathrm{P}$ in a form easily available for plants, and the feasibility for integrating other nutrients such as $\mathrm{K}$, will need further research efforts.

The development and implementation of $\mathrm{P}$ recovery technologies to produce marketable by-products most probably can help to reduce dependence on finite raw materials, while providing side-benefits in WWTP sludge lines. However, net impacts related to global warming are highly dependent on the structure of the productive sector at the regional level (e.g., nutrient balance, local stakeholders, and existence of enterprises dedicated to produce fertilisers). The materialisation of P-recovered fertilisers is not only cost-dependent, but it is also subjected to other decisions that impact on the need to process eligible input materials. Systematic studies based on mass flow analysis, life cycle assessment, and the definition of objective indicators to quantify sustainability and costs will help to assess the final benefits of the technological alternatives here described. A holistic approach, taking into account the water-environmental technology-agronomy nexus will favour the achievement of those requirements needed for an optimised production of fertilising products. Nowadays, most of the data used to assess the agronomic efficiency of these recovered products have been obtained in pot experiments. More field tests are, therefore, required for a better assessment of the performance of these products as fertilisers. In this regard, there is a lack of information about their performance in the long-term and their effect on both plant production and soil quality. The accumulation of plant-unavailable $\mathrm{P}$ in the soil may lead to an increased risk of P-losses through leaching and run-off. Moreover, the accumulation of other organic (micro)pollutants may also trigger contamination events affecting biodiversity, key soil functions, and its potential transference to crops (which, in turn, might be associated with impacts on human health).

Supplementary Materials: The following are available online at http://www.mdpi.com/2073-4395/10/7/1039/s1, Relevant words included (or discarded) in the multi-term topic search assessed via the Web of Science Core Collection (Clarivate Analytics, USA).

Author Contributions: Conceptualization, A.M. and M.C.-S.; methodology, A.M.; software, A.M.; validation, A.M.; formal analysis, A.M.; data curation, A.M.; writing—original draft preparation, A.M. and M.C.-S.; writing-review and editing, A.M., M.C.-S., C.B. and J.C.; project administration, A.M.; funding acquisition, C.B. and J.C. All authors have read and agreed to the published version of the manuscript.

Funding: At University of Girona (UdG), this paper was written in the framework of the research project DigesTake (Resource recovery and valorisation from urban digestates in the framework of the circular economy) [COMRDI16-1-0061] funded by ACCIÓ-Generalitat de Catalunya within the program Comunitat RIS3CAT Aigua. The Laboratory of Chemical and Environmental Engineering (LEQUIA) (http://www.lequia.udg.edu/) is member of the TECNIO network, and it has been recognised as a consolidated research group by the Catalan Government [2017 SGR 1552]. At the Institute of Agrifood Research and Technology (IRTA), this paper was written in the framework of the research project LIFE ENRICH (Enhanced nitrogen and phosphorous recovery from wastewater and integration in the value chain) [LIFE16 ENV/ES/000375]. IRTA received the support of the CERCA Program-Generalitat de Catalunya.

Acknowledgments: The authors thank the efforts made by Dr. Rafaela Cáceres to make this scientific collaboration between UdG and IRTA possible. The authors would also like to acknowledge the constructive comments posed by the anonymous reviewers during the peer-review process, which helped to improve the final version of the paper. 
Conflicts of Interest: The authors declare no conflict of interest.

\section{References}

1. Cordell, D.; White, S. Peak phosphorus: Clarifying the key issues of a vigorous debate about long-term phosphorus security. Sustainability 2011, 3, 2027-2049. [CrossRef]

2. Penuelas, J.; Sardans, J.; Alcaniz, J.M.; Poch, J.M. Increased eutrophication and nutrient imbalances in the agricultural soil of NE Catalonia, Spain. J. Environ. Biol. 2009, 30, 841-846. [PubMed]

3. Cordell, D.; Drangert, J.-O.; White, S. The story of phosphorus: Global food security and food for thought. Glob. Environ. Change-Human Policy Dimens. 2009, 19, 292-305. [CrossRef]

4. Gilbert, N. The disappearing nutrient. Nature 2009, 461, 716-718. [CrossRef]

5. Elser, J.; Bennett, E. A broken biogeochemical cycle. Nature 2011, 478, 29-31. [CrossRef]

6. European Commission. Communication from the Commission to the European Parliament, the Council, the European Economic and Social Committee and the Committee of the Regions on the 2017 List of Critical Raw Materials for the EU. 2017. COM(2017) 490. Available online: https://ec.europa.eu/transparency/regdoc/ rep/1/2017/EN/COM-2017-490-F1-EN-MAIN-PART-1.PDF (accessed on 27 May 2020).

7. Withers, P.J.A.; Elser, J.J.; Hilton, J.; Ohtake, H.; Schippere, W.J.; van Dijkf, K.C. Greening the global phosphorus cycle: How green chemistry can help achieve planetary P sustainability. Green Chem. 2015, 17, 2087-2099. [CrossRef]

8. Rittmann, B.E.; Mayer, B.; Westerhoff, P.; Edwards, M. Capturing the lost phosphorus. Chemosphere 2011, 84, 846-853. [CrossRef]

9. Desmidt, E.; Ghyselbrecht, K.; Zhang, Y.; Pinoy, L.; Van der Bruggen, B.; Verstraete, W.; Rabaey, K.; Meesschaert, B. Global phosphorus scarcity and full-scale P-recovery techniques: A review. Crit. Rev. Environ. Sci. Technol. 2015, 45, 336-384. [CrossRef]

10. Egle, L.; Rechberger, H.; Krampe, J.; Zessner, M. Phosphorus recovery from municipal wastewater: An integrated comparative technological, environmental and economic assessment of P recovery technologies. Sci. Total Environ. 2016, 571, 522-542. [CrossRef]

11. Snoeyink, V.L.; Jenkins, D. Water Chemistry; John Wiley \& Sons Inc.: New York, NY, USA, 1980.

12. Le Corre, K.S.; Valsami-Jones, E.; Hobbs, P.; Parsons, S.A. Phosphorus recovery from wastewater by struvite crystallization: A review. Crit. Rev. Environ. Sci. Technol. 2009, 39, 433-477. [CrossRef]

13. Kataki, S.; West, H.; Clarke, M.; Baruah, D.C. Phosphorus recovery as struvite from farm, municipal and industrial waste: Feedstock suitability, methods and pre-treatments. Waste Manag. 2016, 49, 437-454. [CrossRef] [PubMed]

14. Song, Y.; Hahn, H.H.; Hoffmann, E. The effect of carbonate on the precipitation of calcium phosphate. Environ. Technol. 2002, 23, 207-215. [CrossRef] [PubMed]

15. Law, K.P.; Pagilla, K.R. Phosphorus recovery by methods beyond struvite precipitation. Water Environ. Res. 2018, 90, 840-850. [CrossRef]

16. Wilfert, P.; Kumar, P.S.; Korving, L.; Witkamp, G.-J.; van Loosdrecht, M.C.M. The relevance of phosphorus and iron chemistry to the recovery of phosphorus from wastewater: A review. Environ. Sci. Technol. 2015, 16, 9400-9414. [CrossRef] [PubMed]

17. Wilfert, P.; Dugulan, A.I.; Goubitz, K.; Korving, L.; Witkamp, G.J.; Van Loosdrecht, M.C.M. Vivianite as the main phosphate mineral in digested sewage sludge and its role for phosphate recovery. Water Res. 2018, 144, 312-321. [CrossRef]

18. Wang, S.; An, J.; Wan, Y.; Du, Q.; Wang, X.; Cheng, X.; Li, N. Phosphorus competition in bioinduced vivianite recovery from wastewater. Environ. Sci. Technol. 2018, 52, 13863-13870. [CrossRef]

19. Wu, Y.; Luo, J.; Zhang, Q.; Aleem, M.; Fang, F.; Xue, Z.; Cao, J. Potentials and challenges of phosphorus recovery as vivianite from wastewater: A review. Chemosphere 2019, 226, 246-258. [CrossRef]

20. Prot, T.; Wijdeveld, W.; Ekua Eshun, L.; Dugulan, A.I.; Goubitz, K.; Korving, L.; Van Loosdrecht, M.C.M. Full-scale increased iron dosage to stimulate the formation of vivianite and its recovery from digested sewage sludge. Water Res. 2020, 182, 115911. [CrossRef]

21. Cornel, P.; Schaum, C. Phosphorus recovery from wastewater: Needs, technologies and costs. Water Sci. Technol. 2009, 59, 1069-1076. [CrossRef]

22. Borgerding, J. Phosphate deposits in digestion systems. J. Water Pollut. Control Fed. 1972, 44, 813-819. 
23. Buchanan, J.R.; Mote, C.R.; Robinson, R.B. Struvite control by chemical treatment. Trans. ASAE 1994, 37, 1301-1308. [CrossRef]

24. Doyle, J.D.; Parsons, S.A. Struvite formation, control and recovery. Water Res. 2002, 36, 3925-3940. [CrossRef]

25. Sharp, R.; Vadiveloo, E.; Fergen, R.; Moncholi, M.; Pitt, P.; Wankmuller, D.; Latimer, R. A theoretical and practical evaluation of struvite control and recovery. Water Environ. Res. 2013, 85, 675-686. [CrossRef] [PubMed]

26. Geerts, S.; Marchi, A.; Weemaes, M. Full-scale phosphorus recovery from digested wastewater sludge in Belgium-Part II: Economic opportunities and risks. Water Sci. Technol. 2015, 71, 495-502. [CrossRef]

27. Marchi, A.; Geerts, S.; Weemaes, M.; Wim, S.; Christine, V. Full-scale phosphorus recovery from digested waste water sludge in Belgium-Part I: Technical achievements and challenges. Water Sci. Technol. 2015, 71, 487-494. [CrossRef] [PubMed]

28. Ueno, Y.; Fujii, M. Three years experience of operating and selling recovered struvite from full scale plant. Environ. Technol. 2001, 22, 1373-1381. [CrossRef]

29. Van Hulle, S.W.H.; Vandeweyer, H.J.P.; Meesschaert, B.D.; Vanrolleghem, P.A.; Dejans, P.; Dumoulin, A. Engineering aspects and practical application of autotrophic nitrogen removal from nitrogen rich streams. Chem. Eng. J. 2010, 162, 1-20. [CrossRef]

30. Magrí, A.; Béline, F.; Dabert, P. Feasibility and interest of the anammox process as treatment alternative for anaerobic digester supernatants in manure processing-An overview. J. Environ. Manag. 2013, 131, 170-184. [CrossRef]

31. Lackner, S.; Gilbert, E.M.; Vlaeminck, S.E.; Joss, A.; Horn, H.; van Loosdrecht, M.C.M. Full-scale partial nitritation/anammox experiences-An application survey. Water Res. 2014, 55, 292-303. [CrossRef]

32. Kumwimba, M.N.; Lotti, T.; Şenel, E.; Li, X.; Suanon, F. Anammox-based processes: How far have we come and what work remains? A review by bibliometric analysis. Chemosphere 2019, 238, 124627. [CrossRef]

33. Ndegwa, P.M.; Hristov, A.N.; Arogo, J.; Sheffield, R.E. A review of ammonia emission mitigation techniques for concentrated animal feeding operations. Biosyst. Eng. 2008, 100, 453-469. [CrossRef]

34. Fumasoli, A.; Etter, B.; Sterkele, B.; Morgenroth, E.; Udert, K.M. Operating a pilot-scale nitrification/distillation plant for complete nutrient recovery from urine. Water Sci. Technol. 2016, 73, 215-222. [CrossRef]

35. Magrí, A. Research trends on nutrient management from digestates assessed using a bibliometric approach. Front. Sustain. Food Syst. 2018, 2, 40. [CrossRef]

36. Egle, L.; Rechberger, H.; Zessner, M. Overview and description of technologies for recovering phosphorus from municipal wastewater. Resour. Conserv. Recycl. 2015, 105, 325-346. [CrossRef]

37. Liu, Y.H.; Kumar, S.; Kwag, J.-H.; Ra, C.S. Magnesium ammonium phosphate formation, recovery and its application as valuable resources: A review. J. Chem. Technol. Biotechnol. 2013, 88, 181-189. [CrossRef]

38. Reijnders, L. Phosphorus resources, their depletion and conservation, a review. Resour. Conserv. Recycl. 2014, 93, 32-49. [CrossRef]

39. Kataki, S.; West, H.; Clarke, M.; Baruah, D.C. Phosphorus recovery as struvite: Recent concerns for use of seed, alternative Mg source, nitrogen conservation and fertilizer potential. Resour. Conserv. Recycl. 2016, 107, 142-156. [CrossRef]

40. Tao, W.; Fattah, K.P.; Huchzermeier, M.P. Struvite recovery from anaerobically digested dairy manure: A review of application potential and hindrances. J. Environ. Manag. 2016, 169, 46-57. [CrossRef]

41. Sena, M.; Hicks, A. Life cycle assessment review of struvite precipitation in wastewater treatment. Resour. Conserv. Recycl. 2018, 139, 194-204. [CrossRef]

42. Chrispim, M.C.; Scholz, M.; Nolasco, M.A. Phosphorus recovery from municipal wastewater treatment: Critical review of challenges and opportunities for developing countries. J. Environ. Manag. 2019, 248, 109268. [CrossRef]

43. Ghosh, S.; Lobanov, S.; Lo, V.K. An overview of technologies to recover phosphorus as struvite from wastewater: Advantages and shortcomings. Environ. Sci. Pollut. Res. 2019, 26, 19063-19077. [CrossRef]

44. Li, B.; Huang, H.M.; Boiarkina, I.; Yu, W.; Huang, Y.F.; Wang, G.Q.; Young, B.R. Phosphorus recovery through struvite crystallisation: Recent developments in the understanding of operational factors. J. Environ. Manag. 2019, 248, 109254. [CrossRef]

45. Clark, J.S. Solubility criteria for the existence of hydroxyapatite. Can. J. Chem. 1955, 33, 1696-1700. [CrossRef]

46. Taylor, A.W.; Frazier, A.W.; Gurney, E.L. Solubility products of magnesium ammonium and magnesium potassium phosphates. Trans. Faraday Soc. 1963, 59, 1580-1584. [CrossRef] 
47. Luff, B.B.; Reed, R.B. Thermodynamic properties of magnesium potassium orthophosphate hexahydrate. J. Chem. Eng. Data 1980, 25, 310-312. [CrossRef]

48. Ohlinger, K.N.; Young, T.M.; Schroeder, E.D. Predicting struvite formation in digestion. Water Res. 1998, 32, 3607-3614. [CrossRef]

49. Jenkins, D.; Ferguson, J.F.; Menar, A.B. Chemical processes for phosphate removal. Water Res. 1971, 5, 369-389. [CrossRef]

50. Yeoman, S.; Stephenson, T.; Lester, J.N.; Perry, R. The removal of phosphorus during wastewater treatment: A review. Environ. Pollut. 1988, 49, 183-233. [CrossRef]

51. Bunce, J.T.; Ndam, E.; Ofiteru, I.D.; Moore, A.; Graham, D.W. A review of phosphorus removal technologies and their applicability to small-scale domestic wastewater treatment systems. Front. Environ. Sci. 2018, 6, 8. [CrossRef]

52. Arvin, E. Calcium phosphate precipitation in a denitrifying biofilm-The conceptual basis. In Kinetics of Wastewater Treatment; Jenkins, S.H., Ed.; Pergamon Press: Oxford, UK, 1979; pp. 1-17. [CrossRef]

53. Salutsky, M.L.; Shapiro, J.J.; Dunseth, M.G.; Ries, K.M. Ultimate disposal of phosphate from waste water by recovery as fertilizer. Effl. Water Treat. J. 1972, 12, 509-519.

54. Stratful, I.; Brett, S.; Scrimshaw, M.B.; Lester, J.N. Biological phosphorus removal, its role in phosphorus recycling. Environ. Technol. 1999, 20, 681-695. [CrossRef]

55. Arvin, E.; Kristensen, G.H. Phosphate precipitation in biofilms and flocs. Water Sci. Technol. 1983, 15, 65-85. [CrossRef]

56. Vereecke, G.; Lemaître, J. Calculation of the solubility diagrams in the system $\mathrm{Ca}(\mathrm{OH})_{2}-\mathrm{H}_{3} \mathrm{PO}_{4}-\mathrm{KOH}_{-}-\mathrm{HNO}_{3}-$ $\mathrm{CO}_{2}-\mathrm{H}_{2}$ O. J. Cryst. Growth. 1990, 104, 820-832. [CrossRef]

57. Buchanan, J.R.; Mote, C.R.; Robinson, R.B. Thermodynamics of struvite formation. Trans. ASAE 1994, 37, 617-621. [CrossRef]

58. Musvoto, E.V.; Wentzel, M.C.; Ekama, G.A. Integrated chemical-physical processes modelling-II. Simulating aeration treatment of anaerobic digester supernatants. Water Res. 2000, 34, 1868-1880. [CrossRef]

59. Udert, K.M.; Larsen, T.A.; Gujer, W. Estimating the precipitation potential in urine-collecting systems. Water Res. 2003, 37, 2667-2677. [CrossRef]

60. Gustafsson, J.P. Visual MINTEQ, ver. 3.1. 2018. Available online: https://vminteq.lwr.kth.se/ (accessed on 27 May 2020).

61. van Dijk, J.C.; Braakensiek, H. Phosphate removal by crystallization in a fluidized bed. Water Sci. Technol. 1985, 17, 133-142. [CrossRef]

62. Giesen, A. Crystallisation process enables environmental friendly phosphate removal at low costs. Environ. Technol. 1999, 20, 769-775. [CrossRef]

63. Johnston, A.E.; Richards, I.R. Effectiveness of different precipitated phosphates as phosphorus sources for plants. Soil Use Manag. 2003, 19, 45-49. [CrossRef]

64. Römer, W.; Steingrobe, B. Fertilizer effect of phosphorus recycling products. Sustainability 2018, 10, 1166. [CrossRef]

65. Szymańska, M.; Szara, E.; Wąs, A.; Sosulski, T.; van Pruissen, G.W.P.; Cornelissen, R.L. Struvite-An innovative fertilizer from anaerobic digestate produced in a bio-refinery. Energies 2019, 12, 296. [CrossRef]

66. Maekawa, T.; Liao, C.-M.; Feng, X.-D. Nitrogen and phosphorus removal for swine wastewater using intermittent aeration batch reactor followed by ammonium crystallization process. Water Res. 1995, 29, 2643-2650. [CrossRef]

67. Caffaz, S.; Bettazzi, E.; Scaglione, D.; Lubello, C. An integrated approach in a municipal WWTP: Anaerobic codigestion of sludge with organic waste and nutrient removal from supernatant. Water Sci. Technol. 2008, 58, 669-676. [CrossRef] [PubMed]

68. Tian, X.; Gao, Z.; Feng, H.; Zhang, Z.; Li, J.; Wang, A. Efficient nutrient recovery/removal from real source-separated urine by coupling vacuum thermal stripping with activated sludge processes. J. Clean. Prod. 2019, 220, 965-973. [CrossRef]

69. Yang, S.; Xu, S.; Florentino, A.P.; Mohammed, A.; Ashbolt, N.J.; Liu, Y. Importance of controlling phosphate concentration in nitritation-anammox reactor operation. Environ. Sci. Water Res. Technol. 2019, 5, 1234-1243. [CrossRef]

70. Johansson, S.; Ruscalleda, M.; Colprim, J. Phosphorus recovery through biologically induced precipitation by partial nitritation-anammox granular biomass. Chem. Eng. J. 2017, 327, 881-888. [CrossRef] 
71. Pambrun, V.; Paul, E.; Spérandio, M. Treatment of nitrogen and phosphorus in highly concentrated effluent in SBR and SBBR processes. Water Sci. Technol. 2004, 50, 269-276. [CrossRef] [PubMed]

72. Ma, H.; Zhang, Y.; Xue, Y.; Li, Y.-Y. A new process for simultaneous nitrogen removal and phosphorus recovery using an anammox expanded bed reactor. Bioresour. Technol. 2018, 267, 201-208. [CrossRef]

73. Vanotti, M.B.; Szogi, A.; Hunt, P.G. Extraction of soluble phosphorus from swine wastewater. Trans. ASAE 2003, 46, 1665-1674. [CrossRef]

74. Suzin, L.; Antes, F.G.; Bedendo, G.C.; Bortoli, M.; Kunz, A. Chemical removal of phosphorus from swine effluent: The impact of previous effluent treatment technologies on process efficiency. Water Air Soil Pollut. 2018, 229, 341. [CrossRef]

75. Tarragó, E.; Ruscalleda, M.; Colprim, J.; Balaguer, M.D.; Puig, S. Towards a methodology for recovering K-struvite from manure. J. Chem. Technol. Biotechnol. 2018, 93, 1558-1562. [CrossRef]

76. Johansson, S.; Ruscalleda, M.; Saerens, B.; Colprim, J. Potassium recovery from centrate: Taking advantage of autotrophic nitrogen removal for multi-nutrient recovery. J. Chem. Technol. Biotechnol. 2019, 94, 819-828. [CrossRef]

77. Agrawal, S.; Guest, J.S.; Cusick, R.D. Elucidating the impacts of initial supersaturation and seed crystal loading on struvite precipitation kinetics, fines production, and crystal growth. Water Res. 2018, 132, $252-259$. [CrossRef]

78. Forrest, A.L.; Fattah, K.P.; Mavinic, D.S.; Koch, F.A. Optimizing struvite production for phosphate recovery in WWTP. J. Environ. Eng. 2008, 134, 395-402. [CrossRef]

79. Udert, K.M.; Larsen, T.A.; Biebow, M.; Gujer, W. Urea hydrolysis and precipitation dynamics in a urine-collecting system. Water Res. 2003, 37, 2571-2582. [CrossRef]

80. Salutsky, M.L.; Steiger, R.P. Properties of fertilizer materials, metal potassium phosphates. J. Agric. Food Chem. 1964, 12, 486-491. [CrossRef]

81. Wilsenach, J.A.; Schuurbiers, C.A.H.; van Loosdrecht, M.C.M. Phosphate and potassium recovery from source separated urine through struvite precipitation. Water Res. 2007, 41, 458-466. [CrossRef]

82. Abbona, F.; Lundager-Madsen, H.E.; Boistelle, R. Crystallization of two magnesium phosphates, struvite and newberyite: Effect of pH and concentration. J. Cryst. Growth. 1982, 57, 6-14. [CrossRef]

83. Boistelle, R.; Abbona, F.; Lundager-Madsen, H.E. On the transformation of struvite into newberyite in aqueous systems. Phys. Chem. Miner. 1983, 9, 216-222. [CrossRef]

84. Tung, M.S. Calcium phosphates: Structure, composition, solubility, and stability. In Calcium Phosphates in Biological and Industrial Systems; Amjad, Z., Ed.; Kluwer Academic Publishers: Boston, MA, USA, 1998.

85. Moreno, E.C.; Gregory, T.M.; Brown, W.E. Preparation and solubility of hydroxyapatite. J. Res. Natl. Bur. Stand. A Phys. Chem. 1968, 72A,773-782. [CrossRef]

86. Johnsson, M.S.-A.; Nancollas, G.H. The role of brushite and octacalcium phosphate in apatite formation. Crit. Rev. Oral Biol. Med. 1992, 3, 61-82. [CrossRef] [PubMed]

87. Drouet, C. Why it may not work as planned, and how to conclusively identify apatite compounds. BioMed Res. Int. 2013, 2013, 490946. [CrossRef] [PubMed]

88. Hao, X.; Wang, C.; van Loosdrecht, M.C.M.; Hu, Y. Looking beyond struvite for P-recovery. Environ. Sci. Technol. 2013, 47, 4965-4966. [CrossRef]

89. Taylor, A.W.; Frazier, A.W.; Gurney, E.L.; Smith, J.P. Solubility products of di- and trimagnesium phosphates and the dissociation of magnesium phosphate solutions. Trans. Faraday Soc. 1963, 59, 1585-1589. [CrossRef]

90. Nriagu, J.O. Stability of vivianite and ion-pair formation in the system $\mathrm{Fe}_{3}\left(\mathrm{PO}_{4}\right)_{2}-\mathrm{H}_{3} \mathrm{PO}_{4}-\mathrm{H}_{2} \mathrm{O}$. Geochim. Cosmochim. Acta 1972, 36, 459-470. [CrossRef]

91. Vlaeminck, S.E.; De Clippeleir, H.; Verstraete, W. Microbial resource management of one-stage partial nitritation/anammox. Microb. Biotechnol. 2012, 5, 433-448. [CrossRef] [PubMed]

92. van Rensburg, P.; Musvoto, E.V.; Wentzel, M.C.; Ekama, G.A. Modelling multiple mineral precipitation in anaerobic digester liquor. Water Res. 2003, 37, 3087-3097. [CrossRef]

93. Fattah, K.P.; Sabrina, N.; Mavinic, D.S.; Koch, F.A. Reducing operating costs for struvite formation with a carbon dioxide stripper. Water Sci. Technol. 2008, 58, 957-962. [CrossRef]

94. Janus, H.M.; van der Roest, H.F. Don't reject the idea of treating reject water. Water Sci. Technol. 1997, 35, 27-34. [CrossRef]

95. van Loosdrecht, M.C.M.; Salem, S. Biological treatment of sludge digester liquids. Water Sci. Technol. 2006, 53, 11-20. [CrossRef] 
96. De Vrieze, J.; Smet, D.; Klok, J.; Colsen, J.; Angenent, L.T.; Vlaeminck, S.E. Thermophilic sludge digestion improves energy balance and nutrient recovery potential in full-scale municipal wastewater treatment plants. Bioresour. Technol. 2016, 218, 1237-1245. [CrossRef]

97. van der Kooij, S.; van Vliet, B.J.M.; Stomph, T.J.; Sutton, N.B.; Anten, N.P.R.; Hoffland, E. Phosphorus recovered from human excreta: A socio-ecological-technical approach to phosphorus recycling. Resour. Conserv. Recycl. 2020, 157, 104744. [CrossRef]

98. Shaddel, S.; Ucar, S.; Andreassen, J.-P.; Østerhus, S.W. Enhancing efficiency and economics of phosphorus recovery process by customizing the product based on sidestream characteristics-An alternative phosphorus recovery strategy. Water Sci. Technol. 2019, 79, 1777-1789. [CrossRef] [PubMed]

99. Vanotti, M.B.; Ro, K.S.; Szogi, A.A.; Loughrin, J.H.; Millner, P.D. High-rate solid-liquid separation coupled with nitrogen and phosphorus treatment of swine manure: Effect on water quality. Front. Sustain. Food Syst. 2018, 2, 49. [CrossRef]

100. Petzet, S.; Cornel, P. Towards a complete recycling of phosphorus in wastewater treatment-Options in Germany. Water Sci. Technol. 2011, 64, 29-35. [CrossRef]

101. Piveteau, S.; Picard, S.; Dabert, P.; Daumer, M.-L. Dissolution of particulate phosphorus in pig slurry through biological acidification: A critical step for maximum phosphorus recovery as struvite. Water Res. 2017, 124, 693-701. [CrossRef]

102. Kok, D.-J.D.; Pande, S.; van Lier, J.B.; Ortigara, A.R.C.; Savenije, H.; Uhlenbrook, S. Global phosphorus recovery from wastewater for agricultural reuse. Hydrol. Earth Syst. Sci. 2018, 22, 5781-5799. [CrossRef]

103. Hao, X.-D.; van Loosdrecht, M.C.M. A proposed sustainable BNR plant with the emphasis on recovery of COD and phosphate. Water Sci. Technol. 2003, 48, 77-85. [CrossRef]

104. Solon, K.; Flores-Alsina, X.; Mbamba, C.K.; Ikumi, D.; Volcke, E.I.P.; Vaneeckhaute, C.; Ekama, G.; Vanrolleghem, P.A.; Batstone, D.J.; Gernaey, K.V.; et al. Plant-wide modelling of phosphorus transformations in wastewater treatment systems: Impacts of control and operational strategies. Water Res. 2017, 113, 97-110. [CrossRef]

105. Orner, K.; Cools, C.; Balaguer-Barbosa, M.; Zalivina, N.; Mihelcic, J.R.; Chen, G.; Cunningham, J.A. Energy recovery and nitrogen management from struvite precipitation effluent via microbial fuel cells. J. Environ. Eng. 2019, 145, 04018145. [CrossRef]

106. Luo, Z.; Wang, D.; Yang, J.; Huang, H.; Su, G. Nitrogen removal from digested piggery wastewater using fermented superphosphate within the pretreatment stage and an MAP fertilizer pot test. J. Clean. Prod. 2019, 212, 372-380. [CrossRef]

107. Zhu, Z.; Chen, W.; Tao, T.; Li, Y. A novel AAO-SBSPR process based on phosphorus mass balance for nutrient removal and phosphorus recovery from municipal wastewater. Water Res. 2018, 144, 763-773. [CrossRef] [PubMed]

108. Yao, S.; Chen, L.; Guan, D.; Zhang, Z.; Tian, X.; Wang, A.; Wang, G.; Yao, Q.; Peng, D.; Li, J. On-site nutrient recovery and removal from source-separated urine by phosphorus precipitation and short-cut nitrification-denitrification. Chemosphere 2017, 175, 210-218. [CrossRef]

109. Ryu, H.-D.; Choo, Y.-D.; Kang, M.-K.; Lee, S.-I. Integrated application of struvite precipitation and biological treatment in treating autothermal thermophilic aerobic digestion supernatant liquid. Environ. Eng. Sci. 2014, 31, 167-175. [CrossRef]

110. Mackey, H.R.; Zheng, Y.-S.; Tang, W.-T.; Dai, J.; Chen, G.-H. Combined seawater toilet flushing and urine separation for economic phosphorus recovery and nitrogen removal: A laboratory-scale trial. Water Sci. Technol. 2014, 70, 1065-1073. [CrossRef]

111. Guadie, A.; Xia, S.; Zhang, Z.; Guo, W.; Ngo, H.H.; Hermanowicz, S.W. Simultaneous removal of phosphorus and nitrogen from sewage using a novel combo system of fluidized bed reactor-membrane bioreactor (FBR-MBR). Bioresour. Technol. 2013, 149, 276-285. [CrossRef]

112. Shi, J.; Lu, X.; Yu, R.; Zhu, W. Nutrient removal and phosphorus recovery performances of a novel anaerobic-anoxic/nitrifying/induced crystallization process. Bioresour. Technol. 2012, 121, 183-189. [CrossRef]

113. Shi, J.; Lu, X.; Yu, R.; Gu, Q.; Zhou, Y. Influence of wastewater composition on nutrient removal behaviors in the new anaerobic-anoxic/nitrifying/induced crystallization process. Saudi J. Biol. Sci. 2014, 21, 71-80. [CrossRef]

114. Yuan, Q.; Oleszkiewicz, J.A. Biomass fermentation to augment biological phosphorus removal. Chemosphere 2010, 78, 29-34. [CrossRef] 
115. Ryu, H.-D.; Lee, S.-I. Application of struvite precipitation as a pretreatment in treating swine wastewater. Process Biochem. 2010, 45, 563-572. [CrossRef]

116. Chen, M.; He, S.; Yi, Q.; Yang, M. Effect of chloride concentration on nitrogen removal from landfill leachate in sequencing batch reactor after MAP pretreatment. Water Sci. Technol. 2010, 62, 1574-1579. [CrossRef] [PubMed]

117. Li, Y.; Yi, L.; Ma, P.; Zhou, L. Industrial wastewater treatment by the combination of chemical precipitation and immobilized microorganism technologies. Environ. Eng. Sci. 2007, 24, 736-744. [CrossRef]

118. Liao, C.-M.; Maekawa, T.; Feng, X.-D. Nitrogen and phosphorus removal for swine wastewater by ammonium crystallization and intermittent aeration process. J. Environ. Sci. Health Part B Pestic. Contam. Agric. Wastes 1995, 30, 733-758. [CrossRef] [PubMed]

119. Connan, R.; Dabert, P.; Moya-Espinosa, M.; Bridoux, G.; Béline, F.; Magrí, A. Coupling of partial nitritation and anammox in two- and one-stage systems: Process operation, $\mathrm{N}_{2} \mathrm{O}$ emission and microbial community. J. Clean. Prod. 2018, 203, 559-573. [CrossRef]

120. Desmidt, E.; Monballiu, A.; De Clippeleir, H.; Verstraete, W.; Meesschaert, B.D. Autotrophic nitrogen removal after ureolytic phosphate precipitation to remove both endogenous and exogenous nitrogen. Water Sci. Technol. 2013, 67, 1425-1433. [CrossRef] [PubMed]

121. Castro-Barros, C.M.; Daelman, M.R.J.; Mampaey, K.E.; van Loosdrecht, M.C.M.; Volcke, E.I.P. Effect of aeration regime on $\mathrm{N}_{2} \mathrm{O}$ emission from partial nitritation-anammox in a full-scale granular sludge reactor. Water Res. 2015, 68, 793-803. [CrossRef]

122. Abma, W.R.; Driessen, W.; Haarhuis, R.; van Loosdrecht, M.C.M. Upgrading of sewage treatment plant by sustainable and cost-effective separate treatment of industrial wastewater. Water Sci. Technol. 2010, 61, 1715-1722. [CrossRef]

123. Fujimoto, N.; Mizuochi, T.; Togami, Y. Phosphorus fixation in the sludge treatment system of a biological phosphorus removal process. Water Sci. Technol. 1991, 23, 635-640. [CrossRef]

124. Monballiu, A.; Desmidt, E.; Ghyselbrecht, K.; Meesschaert, B. The inhibitory effect of inorganic carbon on phosphate recovery from upflow anaerobic sludge blanket reactor (UASB) effluent as calcium phosphate. Water Sci. Technol. 2018, 78, 2608-2615. [CrossRef]

125. van der Houwen, J.A.M.; Valsami-Jones, E. The application of calcium phosphate precipitation chemistry to phosphorus recovery: The influence of organic ligands. Environ. Technol. 2001, 22, 1325-1335. [CrossRef]

126. Taddeo, R.; Honkanen, M.; Kolppo, K.; Lepistö, R. Nutrient management via struvite precipitation and recovery from various agroindustrial wastewaters: Process feasibility and struvite quality. J. Environ. Manag. 2018, 212, 433-439. [CrossRef] [PubMed]

127. Henze, M.; Harremoës, P.; la Cour Jansen, J.; Arvin, E. Wastewater Treatment, Biological and Chemical Processes; Springer-Verlag: Berlin, Germany, 1995.

128. Tünay, O.; Kabdasli, I.; Orhon, D.; Kolçak, S. Ammonia removal by magnesium ammonium phosphate precipitation in industrial wastewaters. Water Sci. Technol. 1997, 36, 225-228. [CrossRef]

129. Kabdaşlı, I.; Tünay, O.; Özcan, P. Application of struvite precipitation coupled with biological treatment to slaughterhouse wastewaters. Environ. Technol. 2009, 30, 1095-1101. [CrossRef] [PubMed]

130. Kabdaşlı, I.; Tünay, O.; Çetin, M.Ş.; Ölmez, T. Assessment of magnesium ammonium phosphate precipitation for the treatment of leather tanning industry wastewaters. Water Sci. Technol. 2002, 46, 231-239. [CrossRef]

131. Tansel, B.; Lunn, G.; Monje, O. Struvite formation and decomposition characteristics for ammonia and phosphorus recovery: A review of magnesium-ammonia-phosphate interactions. Chemosphere 2018, 194, 504-514. [CrossRef]

132. Qiao, S.; Kanda, R.; Nishiyama, T.; Fujii, T.; Bhatti, Z.; Furukawa, K. Partial nitrification treatment for high ammonium wastewater from magnesium ammonium phosphate process of methane fermentation digester liquor. J. Biosci. Bioeng. 2010, 109, 124-129. [CrossRef]

133. Pintucci, C.; Carballa, M.; Varga, S.; Sarli, J.; Peng, L.; Bousek, J.; Pedizzi, C.; Ruscalleda, M.; Tarragó, E.; Prat, D.; et al. The ManureEcoMine pilot installation: Advanced integration of technologies for the management of organics and nutrients in livestock waste. Water Sci. Technol. 2017, 75, 1281-1293. [CrossRef]

134. Tarragó, E.; Sciarria, T.P.; Ruscalleda, M.; Colprim, J.; Balaguer, M.D.; Adani, F.; Puig, S. Effect of suspended solids and its role on struvite formation from digested manure. J. Chem. Technol. Biotechnol. 2018, 93, 2758-2765. [CrossRef] 
135. Hutnik, N.; Stanclik, A.; Piotrowski, K.; Matynia, A. Recovery of phosphates(V) from wastewaters of different chemical composition. Open Chem. 2019, 17, 1071-1079. [CrossRef]

136. Moragaspitiya, C.; Rajapakse, J.; Millar, G.J. Effect of Ca:Mg ratio and high ammoniacal nitrogen on characteristics of struvite precipitated from waste activated sludge digester effluent. J. Environ. Sci. 2019, 86, 65-77. [CrossRef]

137. Battistoni, P.; De Angelis, A.; Pavan, P.; Prisciandaro, M.; Cecchi, F. Phosphorus removal from a real anaerobic supernatant by struvite crystallization. Water Res. 2001, 35, 2167-2178. [CrossRef]

138. Tarragó, E.; Puig, S.; Ruscalleda, M.; Balaguer, M.D.; Colprim, J. Controlling struvite particles' size using the up-flow velocity. Chem. Eng. J. 2016, 302, 819-827. [CrossRef]

139. Pastor, L.; Mangin, D.; Barat, R.; Seco, A. A pilot-scale study of struvite precipitation in a stirred tank reactor: Conditions influencing the process. Bioresour. Technol. 2008, 99, 6285-6291. [CrossRef] [PubMed]

140. Karakashev, D.; Schmidt, J.E.; Angelidaki, I. Innovative process scheme for removal of organic matter, phosphorus and nitrogen from pig manure. Water Res. 2008, 42, 4083-4090. [CrossRef] [PubMed]

141. Jin, R.-C.; Yang, G.-F.; Yu, J.-J.; Zheng, P. The inhibition of the Anammox process: A review. Chem. Eng. J. 2012, 197, 67-79. [CrossRef]

142. Carvajal-Arroyo, J.M.; Sun, W.; Sierra-Alvarez, R.; Field, J.A. Inhibition of anaerobic ammonium oxidizing (anammox) enrichment cultures by substrates, metabolites and common wastewater constituents. Chemosphere 2013, 91, 22-27. [CrossRef]

143. Zhang, Z.-Z.; Hu, H.-Y.; Xu, J.-J.; Shi, Z.-J.; Deng, R.; Ji, Z.-Q.; Shi, M.-L.; Jin, R.-C. Effects of inorganic phosphate on a high-rate anammox system: Performance and microbial community. Ecol. Eng. 2017, 101, 201-210. [CrossRef]

144. van de Graaf, A.A.; de Bruijn, P.; Robertson, L.A.; Jetten, M.S.M.; Kuenen, J.G. Autotrophic growth of anaerobic ammonium-oxidizing micro-organisms in a fluidized bed reactor. Microbiology 1996, 142, 2187-2196. [CrossRef]

145. Connan, R.; Dabert, P.; Le Roux, S.; Chapleur, O.; Bridoux, G.; Vanotti, M.B.; Béline, F.; Magrí, A. Characterization of a combined batch-continuous procedure for the culture of anammox biomass. Ecol. Eng. 2017, 106, 231-241. [CrossRef]

146. Dapena-Mora, A.; Vázquez-Padín, J.R.; Campos, J.L.; Mosquera-Corral, A.; Jetten, M.S.M.; Méndez, R. Monitoring the stability of an Anammox reactor under high salinity conditions. Biochem. Eng. J. 2010, 51, 167-171. [CrossRef]

147. Lin, Y.M.; Lotti, T.; Sharma, P.K.; van Loosdrecht, M.C.M. Apatite accumulation enhances the mechanical property of anammox granules. Water Res. 2013, 47, 4556-4566. [CrossRef] [PubMed]

148. Gonzalez-Gil, G.; Sougrat, R.; Behzad, A.R.; Lens, P.N.L.; Saikaly, P.E. Microbial community composition and ultrastructure of granules from a full-scale anammox reactor. Microb. Ecol. 2015, 70, 118-131. [CrossRef] [PubMed]

149. Zhang, Z.-Z.; Xu, J.-J.; Hu, H.-Y.; Shi, Z.-J.; Ji, Z.-Q.; Deng, R.; Shi, M.-L.; Jin, R.-C. Insight into the shortand long-term effects of inorganic phosphate on anammox granule property. Bioresour. Technol. 2016, 208, 161-169. [CrossRef] [PubMed]

150. Mann, S. Biomineralization: Principles and Concepts in Bioinorganic Materials Chemistry; Oxford University Press: New York, NY, USA, 2001.

151. Rivadeneyra, M.A.; Ramos-Cormenzana, A.; García-Cervigón, A. Bacterial formation of struvite. Geomicrobiol. J. 1983, 3, 151-163. [CrossRef]

152. Rivadeneyra, M.A.; Pérez-García, I.; Ramos-Cormenzana, A. Struvite precipitation by soil and fresh water bacteria. Curr. Microbiol. 1992, 24, 343-347. [CrossRef]

153. Omelon, S.; Ariganello, M.; Bonucci, E.; Grynpas, M.; Nanci, A. A review of phosphate mineral nucleation in biology and geobiology. Calcif. Tissue Int. 2013, 93, 382-396. [CrossRef]

154. Sánchez-Román, M.; Rivadeneyra, M.A.; Vasconcelos, C.; McKenzie, J.A. Biomineralization of carbonate and phosphate by moderately halophilic bacteria. FEMS Microbiol. Ecol. 2007, 61, 273-284. [CrossRef]

155. Sinha, A.; Singh, A.; Kumar, S.; Khare, S.K.; Ramanan, A. Microbial mineralization of struvite: A promising process to overcome phosphate sequestering crisis. Water Res. 2014, 54, 33-43. [CrossRef]

156. Li, H.; Yao, Q.-Z.; Yu, S.-H.; Huang, Y.-R.; Chen, X.-D.; Fu, S.-Q.; Zhou, G.-T. Bacterially mediated morphogenesis of struvite and its implication for phosphorus recovery. Am. Miner. 2017, 102, 381-390. [CrossRef] 
157. Rivadeneyra, M.A.; Ramos-Cormenzana, A.; García-Cervigón, A. Formation of bobierrite (magnesium phosphate) crystal aggregates by Acinetobacter sp. Mineral. J. 1987, 13, 443-447. [CrossRef]

158. Rivadeneyra, M.A.; Martín-Algarra, A.; Sánchez-Román, M.; Sánchez-Navas, A.; Martín-Ramos, J.D. Amorphous Ca-phosphate precursors for Ca-carbonate biominerals mediated by Chromohalobacter marismortui. ISME J. 2010, 4, 922-932. [CrossRef] [PubMed]

159. Rivadeneyra, M.A.; Delgado, R.; Párraga, J.; Ramos-Cormenzana, A.; Delgado, G. Precipitation of minerals by 22 species of moderately halophilic bacteria in artificial marine salts media: Influence of salt concentration. Folia Microbiol. 2006, 51, 445-453. [CrossRef] [PubMed]

160. Rivadeneyra, M.A.; Pérez-García, I.; Ramos-Cormenzana, A. The effect of incubation temperature on struvite formation by bacteria. Folia Microbiol. 1993, 38, 5-9. [CrossRef]

161. Pérez-García, I.; Rivadeneyra, M.A.; Ramos-Cormenzana, A. The influence of $\mathrm{pH}$ on struvite formation by bacteria. Chemosphere 1989, 18, 1633-1638. [CrossRef]

162. Ben Omar, N.; Entrena, M.; González-Muñoz, M.T.; Arias, J.M.; Huertas, F. Effects of pH and phosphate on the production of struvite by Myxococcus xanthus. Geomicrobiol. J. 1994, 12, 81-90. [CrossRef]

163. Da Silva, S.; Bernet, N.; Delgenès, J.P.; Moletta, R. Effect of culture conditions on the formation of struvite by Myxococcus xanthus. Chemosphere 2000, 40, 1289-1296. [CrossRef]

164. Rivadeneyra, M.A.; Pérez-García, I.; Ramos-Cormenzana, A. Influence of ammonium ion on bacterial struvite production. Geomicrobiol. J. 1992, 10, 125-137. [CrossRef]

165. Pérez-García, I.; Rivadeneyra, M.A.; Quevedo-Sarmiento, J.; Ramos-Cormenzana, A. Struvite formation by Arthrobacter sp. and Pseudomonas sp.: The influence of agitation. Chemosphere 1990, 20, 243-251. [CrossRef]

166. Soares, A.; Veesam, M.; Simoes, F.; Wood, E.; Parsons, S.A.; Stephenson, T. Bio-struvite: A new route to recover phosphorus from wastewater. Clean-Soil Air Water 2014, 42, 994-997. [CrossRef]

167. Pratt, C.; Parsons, S.A.; Soares, A.; Martin, B.D. Biologically and chemically mediated adsorption and precipitation of phosphorus from wastewater. Curr. Opin. Biotechnol. 2012, 23, 890-896. [CrossRef]

168. Bornemann, G.; Waßer, K.; Hauslage, J. The influence of nitrogen concentration and precipitation on fertilizer production from urine using a trickling filter. Life Sci. Space Res. 2018, 18, 12-20. [CrossRef] [PubMed]

169. Sperandio, M.; Pambrun, V.; Paul, E. Simultaneous removal of N and P in a SBR with production of valuable compounds: Application to concentrated wastewaters. Water Sci. Technol. 2008, 58, 859-864. [CrossRef] [PubMed]

170. Zhang, Y.; Ma, H.; Lin, L.; Cao, W.; Ouyang, T.; Li, Y.-Y. Enhanced simultaneous nitrogen and phosphorus removal performance by anammox-HAP symbiotic granules in the attached film expanded bed reactor. ACS Sustain. Chem. Eng. 2018, 6, 10989-10998. [CrossRef]

171. Lin, L.; Zhang, Y.; Beckman, M.; Cao, W.; Ouyang, T.; Wang, S.; Li, Y.-Y. Process optimization of anammox-driven hydroxyapatite crystallization for simultaneous nitrogen removal and phosphorus recovery. Bioresour. Technol. 2019, 290, 121779. [CrossRef] [PubMed]

172. Ma, H.; Xue, Y.; Zhang, Y.; Kobayashi, T.; Kubota, K.; Li, Y.-Y. Simultaneous nitrogen removal and phosphorus recovery using an anammox expanded reactor operated at $25^{\circ} \mathrm{C}$. Water Res. 2020, 172, 115510. [CrossRef]

173. Guo, Y.; Chen, Y.; Webeck, E.; Li, Y.-Y. Towards more efficient nitrogen removal and phosphorus recovery from digestion effluent: Latest developments in the anammox-based process from the application perspective. Bioresour. Technol. 2020, 299, 122560. [CrossRef]

174. Yuan, Z.; Pratt, S.; Batstone, D.J. Phosphorus recovery from wastewater through microbial processes. Curr. Opin. Biotechnol. 2012, 23, 878-883. [CrossRef]

175. Yilmaz, G.; Lemaire, R.; Keller, J.; Yuan, Z. Simultaneous nitrification, denitrification, and phosphorus removal from nutrient-rich industrial wastewater using granular sludge. Biotechnol. Bioeng. 2008, 100, 529-541. [CrossRef]

176. Gonzalez-Martinez, A.; Rodriguez-Sanchez, A.; Rivadeneyra, M.A.; Rivadeneyra, A.; Martin-Ramos, D.; Vahala, R.; Gonzalez-Lopez, J. 16S rRNA gene-based characterization of bacteria potentially associated with phosphate and carbonate precipitation from a granular autotrophic nitrogen removal bioreactor. Appl. Microbiol. Biotechnol. 2017, 101, 817-829. [CrossRef]

177. Simoes, F.; Vale, P.; Stephenson, T.; Soares, A. The role of $\mathrm{pH}$ on the biological struvite production in digested sludge dewatering liquors. Sci. Rep. 2018, 8, 7225. [CrossRef]

178. Leng, Y.; Colston, R.; Soares, A. Understanding the biochemical characteristics of struvite bio-mineralising microorganisms and their future in nutrient recovery. Chemosphere 2020, 247, 125799. [CrossRef] [PubMed] 
179. Rivadeneyra, A.; Gonzalez-Martinez, A.; Gonzalez-Lopez, J.; Martin-Ramos, D.; Martinez-Toledo, M.V.; Rivadeneyra, M.A. Precipitation of phosphate minerals by microorganisms isolated from a fixed-biofilm reactor used for the treatment of domestic wastewater. Int. J. Environ. Res. Public Health 2014, 11, 3689-3704. [CrossRef]

180. Gonzalez-Martinez, A.; Leyva-Díaz, J.C.; Rodriguez-Sanchez, A.; Muñoz-Palazon, B.; Rivadeneyra, A.; Poyatos, J.M.; Rivadeneyra, M.A.; Martinez-Toledo, M.V. Isolation and metagenomic characterization of bacteria associated with calcium carbonate and struvite precipitation in a pure moving bed biofilm reactor-membrane bioreactor. Biofouling 2015, 31, 333-348. [CrossRef]

181. Oa, S.W.; Choi, E. Phosphorus removal from nightsoil with sequencing batch reactor (SBR). Water Sci. Technol. 1997, 36, 55-60. [CrossRef]

182. Daumer, M.L.; Béline, F.; Guiziou, F.; Sperandio, M. Effect of nitrification on phosphorus dissolving in a piggery effluent treated by a sequencing batch reactor. Biosyst. Eng. 2007, 96, 551-557. [CrossRef]

183. Daumer, M.L.; Béline, F.; Guiziou, F.; Sperandio, M. Influence of $\mathrm{pH}$ and biological metabolism on dissolved phosphorus during biological treatment of piggery wastewater. Biosyst. Eng. 2007, 96, 379-386. [CrossRef]

184. Daumer, M.L.; Beline, F.; Guiziou, F. Fate of phosphorus from biological aerobic treatment of pig slurry. By-products characterization and recovery. Environ. Technol. 2003, 24, 1323-1330. [CrossRef]

185. Choi, E.; Yu, Y.; Cui, M.; Yun, Z.; Min, K. Effect of biologically mediated pH change on phosphorus removal in BNR system for piggery waste treatment. J. Environ. Sci. Health Part A 2008, 43, 154-160. [CrossRef]

186. Carlsson, H.; Aspegren, H.; Lee, N.; Hilmer, A. Calcium phosphate precipitation in biological phosphorus removal systems. Water Res. 1997, 31, 1047-1055. [CrossRef]

187. Maurer, M.; Abramovich, D.; Siegrist, H.; Gujer, W. Kinetics of biologically induced phosphorus precipitation in waste-water treatment. Water Res. 1999, 33, 484-493. [CrossRef]

188. Maurer, M.; Boller, M. Modelling of phosphorus precipitation in wastewater treatment plants with enhanced biological phosphorus removal. Water Sci. Technol. 1999, 39, 147-163. [CrossRef]

189. Wong, P.Y.; Cheng, K.Y.; Kaksonen, A.H.; Sutton, D.C.; Ginige, M.P. A novel post denitrification configuration for phosphorus recovery using polyphosphate accumulating organisms. Water Res. 2013, 47, 6488-6495. [CrossRef] [PubMed]

190. Tomei, M.C.; Stazi, V.; Daneshgar, S.; Capodaglio, A.G. Holistic approach to phosphorus recovery from urban wastewater: Enhanced biological removal combined with precipitation. Sustainability 2020, 12, 575. [CrossRef]

191. Li, Y.; Zou, J.; Zhang, L.; Sun, J. Aerobic granular sludge for simultaneous accumulation of mineral phosphorus and removal of nitrogen via nitrite in wastewater. Bioresour. Technol. 2014, 154, 178-184. [CrossRef]

192. Sepúlveda-Mardones, M.; Campos, J.L.; Magrí, A.; Vidal, G. Moving forward in the use of aerobic granular sludge for municipal wastewater treatment: An overview. Rev. Environ. Sci. Bio-Technol. 2019, 18, 741-769. [CrossRef]

193. de Kreuk, M.K.; Heijnen, J.J.; van Loosdrecht, M.C.M. Simultaneous COD, nitrogen and phosphate removal by aerobic granular sludge. Biotechnol. Bioeng. 2005, 90, 761-769. [CrossRef]

194. Mañas, A.; Biscans, B.; Spérandio, M. Biologically induced phosphorus precipitation in aerobic granular sludge process. Water Res. 2011, 45, 3776-3786. [CrossRef]

195. Mañas, A.; Pocquet, M.; Biscans, B.; Sperandio, M. Parameters influencing calcium phosphate precipitation in granular sludge sequencing batch reactor. Chem. Eng. Sci. 2012, 77, 165-175. [CrossRef]

196. Mañas, A.; Spérandio, M.; Decker, F.; Biscans, B. Location and chemical composition of microbially induced phosphorus precipitates in anaerobic and aerobic granular sludge. Environ. Technol. 2012, 33, 2195-2209. [CrossRef]

197. Isanta, E.; Suárez-Ojeda, M.E.; Val del Río, A.; Morales, N.; Pérez, J.; Carrera, J. Long term operation of a granular sequencing batch reactor at pilot scale treating a low-strength wastewater. Chem. Eng. J. 2012, 198-199, 163-170. [CrossRef]

198. Lu, Y.-Z.; Wang, H.-F.; Kotsopoulos, T.A.; Zeng, R.J. Advanced phosphorus recovery using a novel SBR system with granular sludge in simultaneous nitrification, denitrification and phosphorus removal process. Appl. Microbiol. Biotechnol. 2016, 100, 4367-4374. [CrossRef] [PubMed]

199. Hao, W.; Li, Y.; Lv, J.; Chen, L.; Zhu, J. The biological effect of metal ions on the granulation of aerobic granular activated sludge. J. Environ. Sci. 2016, 44, 252-259. [CrossRef] [PubMed] 
200. Barat, R.; Montoya, T.; Seco, A.; Ferrer, J. The role of potassium, magnesium and calcium in the enhanced biological phosphorus removal treatment plants. Environ. Technol. 2005, 26, 983-992. [CrossRef] [PubMed]

201. Lin, Y.M.; Bassin, J.P.; van Loosdrecht, M.C.M. The contribution of exopolysaccharides induced struvites accumulation to ammonium adsorption in aerobic granular sludge. Water Res. 2012, 46, 986-992. [CrossRef] [PubMed]

202. Tervahauta, T.; van der Weijden, R.D.; Flemming, R.L.; Hernández-Leal, L.; Zeeman, G.; Buisman, C.J.N. Calcium phosphate granulation in anaerobic treatment of black water: A new approach to phosphorus recovery. Water Res. 2014, 48, 632-642. [CrossRef]

203. Cunha, J.R.; Tervahauta, T.; van der Weijden, R.D.; Hernández-Leal, L.; Zeeman, G.; Buisman, C.J.N. Simultaneous recovery of calcium phosphate granules and methane in anaerobic treatment of black water: Effect of bicarbonate and calcium fluctuations. J. Environ. Manag. 2018, 216, 399-405. [CrossRef] [PubMed]

204. Cunha, J.R.; Morais, S.; Silva, J.C.; van der Weijden, R.D.; Leal, L.H.; Zeeman, G.; Buisman, C.J.N. Bulk $\mathrm{pH}$ and carbon source are key factors for calcium phosphate granulation. Environ. Sci. Technol. 2019, 53, 1334-1343. [CrossRef] [PubMed]

205. Fernandes, G.W.; Kunz, A.; Steinmetz, R.L.R.; Szogi, A.; Vanotti, M.; Flores, E.M.d.M.; Dressler, V.L. Chemical phosphorus removal: A clean strategy for piggery wastewater management in Brazil. Environ. Technol. 2012, 33, 1677-1683. [CrossRef]

206. Monballiu, A.; Desmidt, E.; Ghyselbrecht, K.; Meesschaert, B. Phosphate recovery as hydroxyapatite from nitrified UASB effluent at neutral $\mathrm{pH}$ in a CSTR. J. Environ. Chem. Eng. 2018, 6, 4413-4422. [CrossRef]

207. Monballiu, A.; Ghyselbrecht, K.; Crabeels, X.; Meesschaert, B. Calcium phosphate precipitation in nitrified wastewater from the potato-processing industry. Environ. Technol. 2019, 40, 2250-2266. [CrossRef]

208. Szogi, A.A.; Vanotti, M.B. Removal of phosphorus from livestock effluents. J. Environ. Qual. 2009, 38, 576-586. [CrossRef] [PubMed]

209. Son, D.-J.; Kim, W.-Y.; Jung, B.-R.; Hong, K.-H. Removal of nitrogen and phosphate from fertilizer industry wastewater by magnesium ammonium phosphate formation and electrochemical treatment. Int. J. Electrochem. Sci. 2019, 14, 3153-3167. [CrossRef]

210. Schuiling, R.D.; Andrade, A. Recovery of struvite from calf manure. Environ. Technol. 1999, 20, 765-768. [CrossRef]

211. Vanotti, M.B.; Millner, P.D.; Hunt, P.G.; Ellison, A.Q. Removal of pathogen and indicator microorganisms from liquid swine manure in multi-step biological and chemical treatment. Bioresour. Technol. 2005, 96, 209-214. [CrossRef] [PubMed]

212. Mazlum, N.; İkizoğlu, B. Nutrient removal by chemical post treatment with lime following the biological stage. Pol. J. Environ. Stud. 2018, 27, 1187-1195. [CrossRef]

213. Vanotti, M.B.; Dube, P.J.; Szogi, A.A.; García-González, M.C. Recovery of ammonia and phosphate minerals from swine wastewater using gas-permeable membranes. Water Res. 2017, 112, 137-146. [CrossRef]

214. Ciceri, D.; Manning, D.A.C.; Allanore, A. Historical and technical developments of potassium resources. Sci. Total Environ. 2015, 502, 590-601. [CrossRef]

215. Manning, D.A.C. How will minerals feed the world in 2050? Proc. Geol. Assoc. 2015, 126, 14-17. [CrossRef]

216. Nakao, S.; Nishio, T.; Kanjo, Y. Simultaneous recovery of phosphorus and potassium as magnesium potassium phosphate from synthetic sewage sludge effluent. Environ. Technol. 2017, 38, 2416-2426. [CrossRef]

217. Le, V.-G.; Vu, C.-T.; Shih, Y.-J.; Bui, X.-T.; Liao, C.-H.; Huang, Y.-H. Phosphorus and potassium recovery from human urine using a fluidized bed homogeneous crystallization (FBHC) process. Chem. Eng. J. 2020, 384. [CrossRef]

218. Xu, K.; Wang, C.; Wang, X.; Qian, Y. Laboratory experiments on simultaneous removal of $\mathrm{K}$ and $\mathrm{P}$ from synthetic and real urine for nutrient recycle by crystallization of magnesium-potassium-phosphatehexahydrate in a draft tube and baffle reactor. Chemosphere 2012, 88, 219-223. [CrossRef] [PubMed]

219. Huang, H.; Li, J.; Li, B.; Zhang, D.; Zhao, N.; Tang, S. Comparison of different K-struvite crystallization processes for simultaneous potassium and phosphate recovery from source-separated urine. Sci. Total Environ. 2019, 651, 787-795. [CrossRef] [PubMed]

220. Xu, K.; Wang, C.; Liu, H.; Qian, Y. Simultaneous removal of phosphorus and potassium from synthetic urine through the precipitation of magnesium potassium phosphate hexahydrate. Chemosphere 2011, 84, 207-212. [CrossRef] [PubMed] 
221. Xu, K.; Li, J.; Zheng, M.; Zhang, C.; Xie, T.; Wang, C. The precipitation of magnesium potassium phosphate hexahydrate for $\mathrm{P}$ and $\mathrm{K}$ recovery from synthetic urine. Water Res. 2015, 80, 71-79. [CrossRef]

222. Huang, H.; Zhang, D.; Wang, W.; Li, B.; Zhao, N.; Li, J.; Dai, J. Alleviating $\mathrm{Na}^{+}$effect on phosphate and potassium recovery from synthetic urine by K-struvite crystallization using different magnesium sources. Sci. Total Environ. 2019, 655, 211-219. [CrossRef]

223. Zhang, C.; Xu, K.-n.; Li, J.-y.; Wang, C.-w.; Zheng, M. Recovery of phosphorus and potassium from source-separated urine using a fluidized bed reactor: Optimization operation and mechanism modeling. Ind. Eng. Chem. Res. 2017, 56, 3033-3039. [CrossRef]

224. Zhang, C.; Xu, K.; Zheng, M.; Li, J.; Wang, C. Factors affecting the crystal size of struvite-K formed in synthetic urine using a stirred reactor. Ind. Eng. Chem. Res. 2018, 57, 17301-17309. [CrossRef]

225. Huygens, D.; Saveyn, H.G.M. Agronomic efficiency of selected phosphorus fertilisers derived from secondary raw materials for European agriculture. A meta-analysis. Agron. Sustain. Dev. 2018, 38, 52. [CrossRef]

226. Schipper, W.J.; Klapwijk, A.; Potjer, B.; Rulkens, W.H.; Temmink, B.G.; Kiestra, F.D.G.; Lijmbach, A.C.M. Phosphate recycling in the phosphorus industry. Environ. Technol. 2001, 22, 1337-1345. [CrossRef]

227. European Parliament and Council of the European Union. Regulation (EU) 2019/1009, Laying Down Rules on the Making Available on the Market of EU Fertilising Products and Amending Regulations (EC) No 1069/2009 and (EC) No 1107/2009 and Repealing Regulation (EC) No 2003/2003. 2019. OJ L-170. pp. 1-114. Available online: http://data.europa.eu/eli/reg/2019/1009/oj (accessed on 27 May 2020).

228. Huygens, S.; Saveyn, H.; Tonini, D.; Eder, P.; Delgado Sancho, L. Technical Proposals for Selected New Fertilising Materials under the Fertilising Products Regulation (Regulation (EU) 2019/1009)_Process and Quality Criteria, and Assessment of Environmental and Market Impacts for Precipitated Phosphate Salts \& Derivates, Thermal Oxidation Materials \& Derivates and Pyrolysis \& Gasification Materials; JRC Science for Policy Report, Publications Office of the European Union: Luxembourg, 2019; EUR 29841 EN. [CrossRef]

229. Giner Santonja, G.; Georgitzikis, K.; Scalet, B.M.; Montobbio, P.; Roudier, S.; Delgado Sancho, L. Best Available Techniques (BAT) Reference Document for the Intensive Rearing of Poultry or Pigs. Industrial Emissions Directive 2010/75/EU. Integrated Pollution Prevention and Control; JRC Science for Policy Report; Publications Office of the European Union: Luxembourg, 2017; EUR 28674 EN. [CrossRef]

230. Boxall, A.B.A. New and Emerging Water Pollutants Arising from Agriculture; OECD: Paris, France, 2012; Available online: http://www.oecd.org/greengrowth/sustainable-agriculture/49848768.pdf (accessed on 27 May 2020).

231. Lou, Y.; Ye, Z.-L.; Chen, S.; Wei, Q.; Zhang, J.; Ye, X. Influences of dissolved organic matters on tetracyclines transport in the process of struvite recovery from swine wastewater. Water Res. 2018, 134, 311-326. [CrossRef]

232. Ye, Z.-L.; Deng, Y.; Lou, Y.; Ye, X.; Chen, S. Occurrence of veterinary antibiotics in struvite recovery from swine wastewater by using a fluidized bed. Front. Environ. Sci. Eng. 2018, 12, 7. [CrossRef]

233. Uysal, A.; Yilmazel, Y.D.; Demirer, G.N. The determination of fertilizer quality of the formed struvite from effluent of a sewage sludge anaerobic digester. J. Hazard. Mater. 2010, 181, 248-254. [CrossRef] [PubMed]

234. STOWA. Verkenning van de Kwaliteit van Struviet uit de Communale Afvalwaterketen (in dutch). STOWA: Amersfoort, Netherlands. 2015. Report 2015-34. Available online: https://www.stowa.nl/sites/default/files/ assets/PUBLICATIES/Publicaties\%202015/STOWA\%202015-34.pdf (accessed on 27 May 2020).

235. Eriksson, J. Concentrations of 61 Trace Elements in Sewage Sludge, Farmyard Manure, Mineral Fertiliser, Precipitation and in Oil and Crops; Swedish Environmental Protection Agency: Stockholm, Sweden, 2001. Available online: http://swedishepa.se/Documents/publikationer/620-6246-8.pdf (accessed on 27 May 2020).

236. Gendebien, A.; Ferguson, R.; Brink, J.; Horth, H.; Sullivan, M.; Davis, R.; Brunet, H.; Dalimier, F.; Landrea, B.; Krack, D.; et al. Survey of Wastes Spread on Land_Final Report; European Commission-DG Environment, Office for Official Publications of the European Communities: Luxembourg, 2001. Available online: https://ec.europa.eu/environment/waste/studies/compost/landspreading.pdf (accessed on 27 May 2020).

237. Karvelas, M.; Katsoyiannis, A.; Samara, C. Occurrence and fate of heavy metals in the wastewater treatment process. Chemosphere 2003, 53, 1201-1210. [CrossRef]

238. Ewert, W.; Hermanussen, O.; Kabbe, C.; Mêlè, C.; Niewersch, C.; Paillard, H.; Stössel, E.; Stemann, J. Comparison of Sludge Related Processes. Sustainable Sewage Sludge Management Fostering Phosphorus Recovery and Energy Efficiency, P-REX Project, FP7-Environment. 2014. Deliverable 5.1. Available online: https://zenodo.org/record/242550/files/P-REX\%20D5.1\%20Comparison\%20of\%20sludge\%20related\% 20processes.pdf?download=1 (accessed on 27 May 2020). 
239. Kahiluoto, H.; Kuisma, M.; Ketoja, E.; Salo, T.; Heikkinen, J. Phosphorus in manure and sewage sludge more recyclable than in soluble inorganic fertilizer. Environ. Sci. Technol. 2015, 49, 2115-2122. [CrossRef]

240. Kratz, S.; Vogel, C.; Adam, C. Agronomic performance of P recycling fertilizers and methods to predict it: A review. Nutr. Cycl. Agroecosyst. 2019, 115, 1-39. [CrossRef]

241. Weissengruber, L.; Möller, K.; Puschenreiter, M.; Friedel, J.K. Long-term soil accumulation of potentially toxic elements and selected organic pollutants through application of recycled phosphorus fertilizers for organic farming conditions. Nutr. Cycl. Agroecosyst. 2018, 110, 427-449. [CrossRef]

242. Yli-Halla, M.; Schick, J.; Kratz, S.; Schnug, E. Determination of plant available P in soil. In Phosphorus in Agriculture: 100\% Zero; Schnug, E., De Kok, L.J., Eds.; Springer Science \& Business Media, B.V.: Dordrecht, Germany, 2016; pp. 63-93. [CrossRef]

243. Cabeza, R.; Steingrobe, B.; Römer, W.; Claassen, N. Effectiveness of recycled P products as P fertilizers, as evaluated in pot experiments. Nutr. Cycl. Agroecosyst. 2011, 91, 173-184. [CrossRef]

244. Degryse, F.; Baird, R.; da Silva, R.C.; McLaughlin, M.J. Dissolution rate and agronomic effectiveness of struvite fertilizers-Effect of soil $\mathrm{pH}$, granulation and base excess. Plant Soil 2017, 410, 139-152. [CrossRef]

245. Möller, K.; Oberson, A.; Bünemann, E.K.; Cooper, J.; Friedel, J.K.; Glæsner, N.; Hörtenhuber, S.; Løes, A.-K.; Mäder, P.; Meyer, G.; et al. Chapter four-Improved phosphorus recycling in organic farming: Navigating between constraints. Adv. Agron. 2018, 147, 159-237. [CrossRef]

246. Brod, E.; Øgaard, A.F.; Haraldsen, T.K.; Krogstad, T. Waste products as alternative phosphorus fertilisers part II: Predicting P fertilization effects by chemical extraction. Nutr. Cycl. Agroecosyst. 2015, 103, 187-199. [CrossRef]

247. Antonini, S.; Arias, M.A.; Eichert, T.; Clemens, J. Greenhouse evaluation and environmental impact assessment of different urine-derived struvite fertilizers as phosphorus sources for plants. Chemosphere 2012, 89, 1202-1210. [CrossRef] [PubMed]

248. European Chemicals Agency. Guidance for Identification and Naming of Substances under REACH and CLP, Version 2.1; ECHA: Helsinki, Finland, 2017. [CrossRef]

249. Cabeza, R.A. Phosphorus Dynamics in Soil and Plant Availability of Fertilizers from Phosphorus Recycling Evaluated in Field and Pot Experiments; Georg-August-Universität Göttingen: Göttingen, Germany; Cuvillier Verlag: Göttingen, Germany, 2010.

250. Wollmann, I.; Gauro, A.; Müller, T.; Möller, K. Phosphorus bioavailability of sewage sludge-based recycled fertilizers. J. Plant Nutr. Soil Sci. 2018, 181, 158-166. [CrossRef]

251. Hall, R.L.; Staal, L.B.; Macintosh, K.A.; McGrath, J.W.; Bailey, J.; Black, L.; Nielsen, U.G.; Reitzel, K.; Williams, P.N. Phosphorus speciation and fertiliser performance characteristics: A comparison of waste recovered struvites from global sources. Geoderma 2020, 362, 114096. [CrossRef]

252. Ackerman, J.N.; Zvomuya, F.; Cicek, N.; Flaten, D. Evaluation of manure-derived struvite as a phosphorus source for canola. Can. J. Plant Sci. 2013, 93, 419-424. [CrossRef]

253. El Diwani, G.; El Rafie, S.; El Ibiari, N.N.; El-Aila, H.I. Recovery of ammonia nitrogen from industrial wastewater treatment as struvite slow releasing fertilizer. Desalination 2007, 214, 200-214. [CrossRef]

254. Vaneeckhaute, C.; Janda, J.; Vanrolleghem, P.A.; Tack, F.M.G.; Meers, E. Phosphorus use efficiency of bio-based fertilizers: Bioavailability and fractionation. Pedosphere 2016, 26, 310-325. [CrossRef]

255. Vogel, C.; Rivard, C.; Wilken, V.; Muskolus, A.; Adam, C. Performance of secondary P-fertilizers in pot experiments analyzed by phosphorus X-ray absorption near edge structure (XANES) spectroscopy. Ambio 2018, 47, S62-S72. [CrossRef] [PubMed]

256. Wang, L.; Nancollas, G.H. Calcium orthophosphates: Crystallization and dissolution. Chem. Rev. 2008, 108, 4628-4669. [CrossRef] [PubMed]

257. Bauer, P.J.; Szogi, A.A.; Vanotti, M.B. Agronomic effectiveness of calcium phosphate recovered from liquid swine manure. Agron. J. 2007, 99, 1352-1356. [CrossRef]

258. Meyer, G.; Frossard, E.; Mäder, P.; Nanzer, S.; Randall, D.G.; Udert, K.M.; Oberson, A. Water soluble phosphate fertilizers for crops grown in calcareous soils-An outdated paradigm for recycled phosphorus fertilizers? Plant Soil 2018, 424, 367-388. [CrossRef]

259. Arai, Y.; Sparks, D.L. Phosphate reaction dynamics in soils and soil components: A multiscale approach. Adv. Agron. 2007, 94, 135-179. [CrossRef]

260. Vasenko, L.; Qu, H. Novel two-stage oxidation/crystallization technology for high-purity calcium phosphates recovery from digester supernatant. J. Environ. Chem. Eng. 2018, 6, 2975-2982. [CrossRef] 
261. Reuter, H.I.; Lado, L.R.; Hengl, T.; Montanarella, L. Continental-scale digital soil mapping using European soil profile data: Soil pH. In SAGA—Seconds Out; Böhner, J., Blaschke, T., Montanarella, L., Eds.; Universität Hamburg, Institut für Geographie: Hamburg, Germany, 2008.

262. Díaz, I.; Barrón, V.; del Campillo, M.C.; Torrent, J. Testing the ability of vivianite to prevent iron deficiency in pot-grown grapevine. Sci. Hortic. 2010, 123, 464-468. [CrossRef]

263. Bisschops, I.; Kjerstadius, H.; Meulman, B.; van Eekert, M. Integrated nutrient recovery from source-separated domestic wastewaters for application as fertilisers. Curr. Opin. Environ. Sustain. 2019, 40, 7-13. [CrossRef]

(C) 2020 by the authors. Licensee MDPI, Basel, Switzerland. This article is an open access article distributed under the terms and conditions of the Creative Commons Attribution (CC BY) license (http://creativecommons.org/licenses/by/4.0/). 